\title{
The Impact of COVID-19 Lockdowns on Mental Health Patient Populations: Evidence from Medical Claims Data*
}

\author{
Ibtihal Ferwana and Lav R. Varshney \\ University of Illinois at Urbana-Champaign \\ \{iferwna2, varshney\}@illinois.edu
}

\begin{abstract}
Background Social distancing policies were enacted during March 2020 to limit the spread of COVID19. Lockdowns and movement restrictions increased the potential of negative impact on population mental health, in which depression and anxiety symptoms were frequently reported by different population groups during COVID-19 lockdown. However, the causal relationship of mitigation policies on national-wide mental health treatment is lacking.
\end{abstract}

Objective This study investigates the effect of COVID-19 mitigation measures on mental health across the United States, on county and state levels. It examines the effect on the total mental health patients, different age and gender groups, and patients of selected mental health diagnoses.

Methods We used large-scale medical claims data for mental health patients dated from September 1 , 2019 to December 31, 2020, with publicly available state- and county-specific COVID-19 cases from first case in January to December 31, 2020, and used publicly available lockdown dates data for states and counties. We designed a difference-in-differences (DID) model, which infers the causal effect of a policy intervention by comparing pre-policy and post-policy periods in different regions. We mainly focused on two types of social distancing policies, stay-at-home and school closure orders.

Results Based on common pre-treatment trend assumption of regions, we find that lockdown has significantly and causally increased seeking medical treatment for mental health across counties and states. Mental health patients in regions with lockdown orders have significantly increased by $18 \%$ compared to $1 \%$ decline in regions without a lockdown. Also, female populations have been exposed to a larger lockdown effect on their mental health with $24 \%$ increase in regions with lockdowns compared to $3 \%$ increase in regions without. While male mental health patients decreased by $5 \%$ in regions without lockdowns. Patients diagnosed with panic disorders and reaction to severe stress both were significantly exposed to a significant large effect of lockdowns. Also, life management difficulty patients doubled in regions with stay-at-home orders but increased less with school closures. Contrarily, attention-deficit hyperactivity patients declined in regions without stay-at-home orders. The number of mental health patients older than 80 decreased in regions with lockdowns. Adults between $(21-40)$ years old were exposed to the greatest lockdown effect with patient number increasing between $20 \%$ to $30 \%$ in regions with lockdown. Adolescent patients under 21 increased in regions with school closures.

Conclusion Although non-pharmaceutical intervention policies were effective in containing the spread of COVID-19, our results show that mitigation policies led to population-wide increase in mental health patients. Our results suggest the need for greater mental health treatment resources in the face of lockdown policies.

* This work was supported in part by NSF grant ECCS-2033900 and by the Center for Pathogen Diagnostics through the ZJU-UIUC Dynamic Engineering Science Interdisciplinary Research Enterprise (DESIRE). There is a Research Data Access and Services Agreement between Change Healthcare Operations, LLC and the Board of Trustees of the University of Illinois. Change Healthcare granted us access and the University of Illinois Urbana-Champaign Institutional Review Board declared this work to be exempt from review.

Corresponding author: Lav R. Varshney (varshney@illinois.edu) 
Keywords: Social Distancing, Pandemics, COVID-19 Policies, Mental Health, Well-being JEL Classification: I1, I12, I18, I31, J1, J18

\section{Introduction}

Following early confirmed COVID-19 cases in late January 2020, people in the United States voluntarily stayed at home and limited their trips and miles traveled, where mobility reduced by $20 \%$ in weeks before any policy interventions in several states [27. As the rate of confirmed cases kept increasing, COVID-19 was formally declared as a global pandemic in early March 2020 [8. Hence, governments around the world issued social distancing policies as a form of non-pharmaceutical intervention to limit contagion spread [39. Social distancing strategies took a variety of forms, from limiting people's gatherings and partially closing schools to fully restricting movements by lockdown orders (also called stay-at-home or shelter-in-place orders) [30. Throughout the country and the world, lockdown proved to be an effective mitigation strategy to contain COVID-19 spread [17, 3, 43. States that implemented stay-at-home orders had their COVID-19 confirmed cases decreases by $48 \%$ and fatalities by $60 \%$ three weeks later [16. However, lockdowns may lead to population-wide economic and mental health side effects. There have been numerous calls for psychological interventions to alleviate the anticipated effects on mental health, either due to the pandemic itself or lockdown orders for its control [12, 9, 1, 26].

Pandemics have previously been associated with high prevalence of post-traumatic stress and anxiety symptoms that can still be detected months or years after disease outbreaks [6. During the COVID-19 pandemic, reported suicidal thoughts and depression symptoms almost quadrupled from 2019 to June 2020 [10] and about 30\% more respondent $\mathrm{s}^{1}$ reported depression and anxiety symptoms than in 2019 in the United States [1. Associated with depression and anxiety, high sleep disturbance and deprived sleep quality have been reported among different population groups, such as adults and healthcare providers 21, 20, 45.

In addition to the mental health impacts of the COVID-19 pandemic itself, there are also mental health impacts from reduced mobility and lockdowns. The restriction of movements brought by social distancing orders reduced physical activity due to shutdown of physical care services and the reduced chances to walk to stores [29. The lack of physical activity has been associated with higher risk of hopelessness and depression [38, 31. During COVID-19 lockdowns, the steps walked by college students have been reduced to half, which was further found to be a leading factor to higher rates in depression [18, 11].

In addition to self-reported and measured depression rates due to COVID-19 mitigation policies, mental health has also been observed online by tracing people's keyword searches. Within the first two weeks after lockdowns, the search for words such as worry, sadness, and boredom peaked in several US states, which has been significantly associated with negative feelings [14, 5].

Some population groups might be more vulnerable to the mental health effects of COVID-19 lockdown than others, particularly people with preexisting psychiatric disorders [47, 29. and people that encountered COVID-19 itself [33. Also, females have been at high risk for exacerbated mental issues, especially working mothers [13, with two-thirds more reporting negative symptoms compared to men [2]. Although elderly people with chronic diseases might be at high risk of developing negative psychological effects [34, they may be more resilient in the face of COVID-19 than younger aged population who have less coping efficacy 24. Most suicidal ideation, stress, and severe depression reports came from people aged 18-24 years old [10, 44, 15] and college students [13] during pandemic social distancing orders compared to older ages. Besides older age, being married (or cohabitant) and having less work-related problems reduce the negative effect of the pandemic and preserve emotional well-being [20, 36].

Although reported numbers show mental health degradation, not all affected people were able to visit psychiatrists due to initial strict lockdown measures. There was a decline by half of usual visits for depression patients during March and April 2020 until they resumed and elevated by June and July 2020 [41, 32, 22, 28, Some institutions offered telemedicine to accommodate for stay-at-home orders [37, 42, though, telemedicine appointments did not fully substitute usual in-person visit volumes [42, 32]. Such inability to seek urgent

\footnotetext{
${ }^{1}$ U.S. Census Bureau December Survey https://www. census.gov/data/tables/2020/demo/hhp/hhp21.html
} 
mental support may lead to an exacerbated psychological effect that appears later and lasts for a longer period of time [37, 6].

To the best of our knowledge, there is no large-scale study that has investigated the extended wider effect of lockdown on mental health patient populations across the country, as the current literature mainly depends on self-reported questionnaires or online behavior patterns. We studied the causal effect of COVID19 mitigation policies on the mental health patient population across counties and states in the United States. We used a large-scale medical claims dataset covering most hospitals in the country to derive results. Our analysis is based on the estimation of the causal effect of difference-in-differences (DID) model which compares the change of outcomes between pre-treatment and post-treatment periods in treated and untreated groups after a policy intervention [4. DID is based on parallel trend assumptions between groups to uphold for causality [4, 19]. Accordingly, based on the DID model, we estimated the effect of lockdown on mental health patients by comparing regions before and after stay-at-home/school closure orders took place. We analyze the effects on total mental health patients, different age and gender groups, and patients of selected mental health diagnoses.

\section{Data}

We used three sets of data to conduct our study: mental health patient claims data, COVID-19 cases data, and lockdown dates data.

For mental health patients data, we used a large de-identified medical claims corpus provided by Change Healthcare for years of 2019 and 2020. Change Healthcare serves 1 million providers covering 5500 hospitals with 220 million patients (which is roughly two-thirds of the US population) and represents over $50 \%$ of private insurance claims across the United States. It covers 51 states/territories and a total of 3141 counties (and equivalent jurisdictions like parishes). The data set includes millions of claims per month from the private insurance marketplace, and some Medicare Advantage programs and Medicaid programs using private insurance carriers, excluding Medicare and Medicaid indemnity claims, which is a limitation in the dataset coverage.

For COVID-19 cases, we considered state-level and county-level cases reported in the United States taken from the New York Times database [40] from the first case date in late January 2020 to December 31, 2020 covering 3218 counties in 51 states/territories.

For lockdown data, we used the data from the COVIDVis project 2 led by the University of California Berkeley to track policy interventions on state and county levels, in which they depended on government pandemic responses to construct the dataset. We considered the dates of two order types, shelter-in-place and $K-12$ school closure in state and county levels. Earliest and latest shelter-in-place orders were on March 14 and April 7, 2020 covering 2598 counties in 43 states. The earliest K-12 school closure was on March 10 and the latest was on April 28, 2020 covering 2465 counties in 39 states. The data is comprehensive, in which states and counties do not appear in the dataset are considered without official imposed lockdown.

\section{Methods}

To estimate the effects of COVID-19 mitigation policies on mental health patients in county and state levels, we conducted difference-in-differences (DID) analysis, which allows for inferring causality based on parallel trends assumption. For DID analysis we considered mental health patients from the date of September 1, 2019 till December 31, 2020. Our approach leveraged the variation of policy mandated dates in different counties or states with 8 states that did not declare an official lockdown. Accordingly, we constructed both treated and control groups to implement the analysis. We estimated the following regression as our main equation for counties Eq. 1 (same as for states Eq. 2):

$$
Y_{c d}=\alpha+\beta_{j} \text { policy }_{j c d}+\delta_{c}+\delta_{d}
$$

\footnotetext{
${ }^{2}$ COVIDVis https://covidvis.berkeley.edu/\#lockdown_section
} 


$$
Y_{s d}=\alpha+\beta_{j} \text { policy }_{j s d}+\delta_{s}+\delta_{d},
$$

where $Y_{c d}$ is the outcome (e.g. total mental health patients) in a given county $c$ or state $s$ on date $d$, policy $_{j c d}$ indicates whether policy $j$ has been mandated for a county $c$ on date $d, \beta_{j}$ is the DID interaction coefficient, representing the effect of introducing policy $j$, and $\delta_{c}$ and $\delta_{d}$ are fixed effects for county and date respectively. County fixed effect is included to adjust for time-invariant (independent of time) unobserved county characteristics that might affect the outcome. For example, each county has its local health care system, social capital index, age profile, and socioeconomic status that the fixed effect controls for. Further, date fixed effect $\delta_{d}$ is included to adjust for factors that vary over time, such as COVID-19 rates or social behavioral change.

Even though DID avoids the bias encountered in time-invariant factors, the bias of time-varying confounders may still be present [23. Therefore, we consider the COVID-19 confirmed cases $x_{c d}$ as a main confounder factor in counties and states. We follow [46] to use a Time-Varying Adjusted (TVA) model, based on the assumption that the confounding variable affect both treated and untreated groups regardless of a policy intervention. We measured the interaction of time and the confounding $x_{c d}$ covariate at county(Eq. 3) and state-level (Eq. 4)

$$
\begin{gathered}
Y_{c d}=\alpha+\beta_{j} \text { policy }_{j c d}+\delta_{c}+\delta_{d} \beta_{0} x_{c d}, \\
Y_{s d}=\alpha+\beta_{j} \text { policy }_{j s d}+\delta_{c}+\delta_{d} \beta_{0} x_{s d} .
\end{gathered}
$$

DID models rely on the assumption of parallel pre-treatment trends to exist in both treated and untreated groups. Hence, in the absence of a policy, treated counties or states would evolve similarly as untreated counties or states. To assess equal pre-policy trends, we designed an event-study type model [19]. We calculated $k$ periods before policy implementation and used an event-study coefficient to indicate whether an outcome in specific date $d$ and county $c$ or state $s$ is within $k$ periods before the policy implementation [35, 14. We estimated the following regression model for counties (Eq. 5) and states (Eq. 6):

$$
\begin{aligned}
& Y_{c d}=\alpha+\beta_{h}^{k} \text { policy }_{h c d}^{k}+\beta_{j} \text { policy }_{j c d}+\delta_{c}+\delta_{d}, \\
& Y_{s d}=\alpha+\beta_{h}^{k} \text { policy }{ }_{h s d}^{k}+\beta_{j} \text { policy }_{j s d}+\delta_{s}+\delta_{d},
\end{aligned}
$$

where policy $y_{h s d}^{k}$, a dummy variable, equals 1 if policy $h$ took place $k$ periods before the mandate, and zero otherwise. Period $k$ is calculated in months, $k=\{-6,-5,-4,-2,-1,0\}$ months, and the month of the policy implementation $(k=0)$ is considered as the omitted category. Here, $\beta_{h}^{k}$ is the event-study coefficient and we included all control variables as defined in equations 1 and 2

\section{Results}

\subsection{Descriptive Analysis}

Before we delve into the causal DID inference, we report some statistics to describe the data of mental health patients. Among 16.7 million mental health patients in the U.S, the mean age was 38.7 years and $56 \%$ were female. As seen in Figure 1, the distribution of mental health patients in states and counties had shifted between 2019 and 2020. The total increase is $22 \%$ of all mental health patients of any mental health disorder as seen in Table B.1 in the appendix.

Figure A.1 in the appendix shows the increasing trend of number of mental health patients, though it decreased between March and April 2020, during lockdown mandates. This supports the findings of [41] where visits of anxiety patients significantly decreased right after strict lockdown took place. An obvious increase was during June 2020, which can be attributed to telemedicine options or relaxed lockdown measures. 
medRxiv preprint doi: https://doi.org/10.1101/2021.05.26.21257598; this version posted June 2, 2021. The copyright holder for this preprint (which was not certified by peer review) is the author/funder, who has granted medRxiv a license to display the preprint in perpetuity.

It is made available under a CC-BY-NC-ND 4.0 International license .
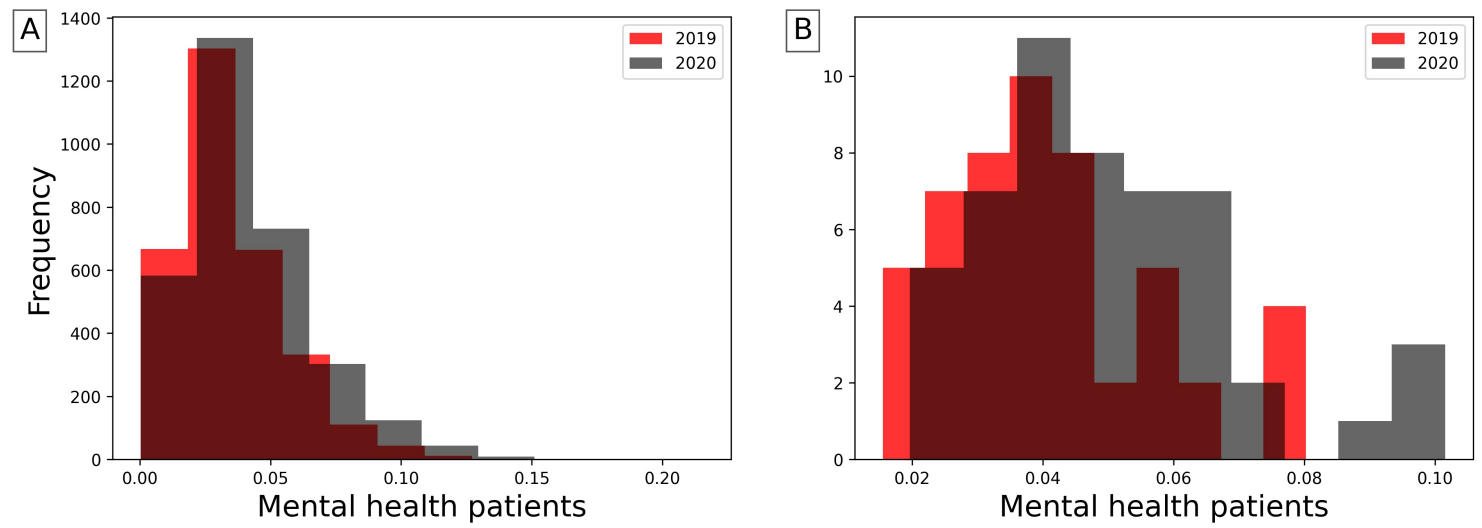

Figure 1: Distributions of mental health patients weighted by regions' populations in years of 2019 and 2020 in counties (A) and states (B). The total population increase is $22 \%$ in 2020

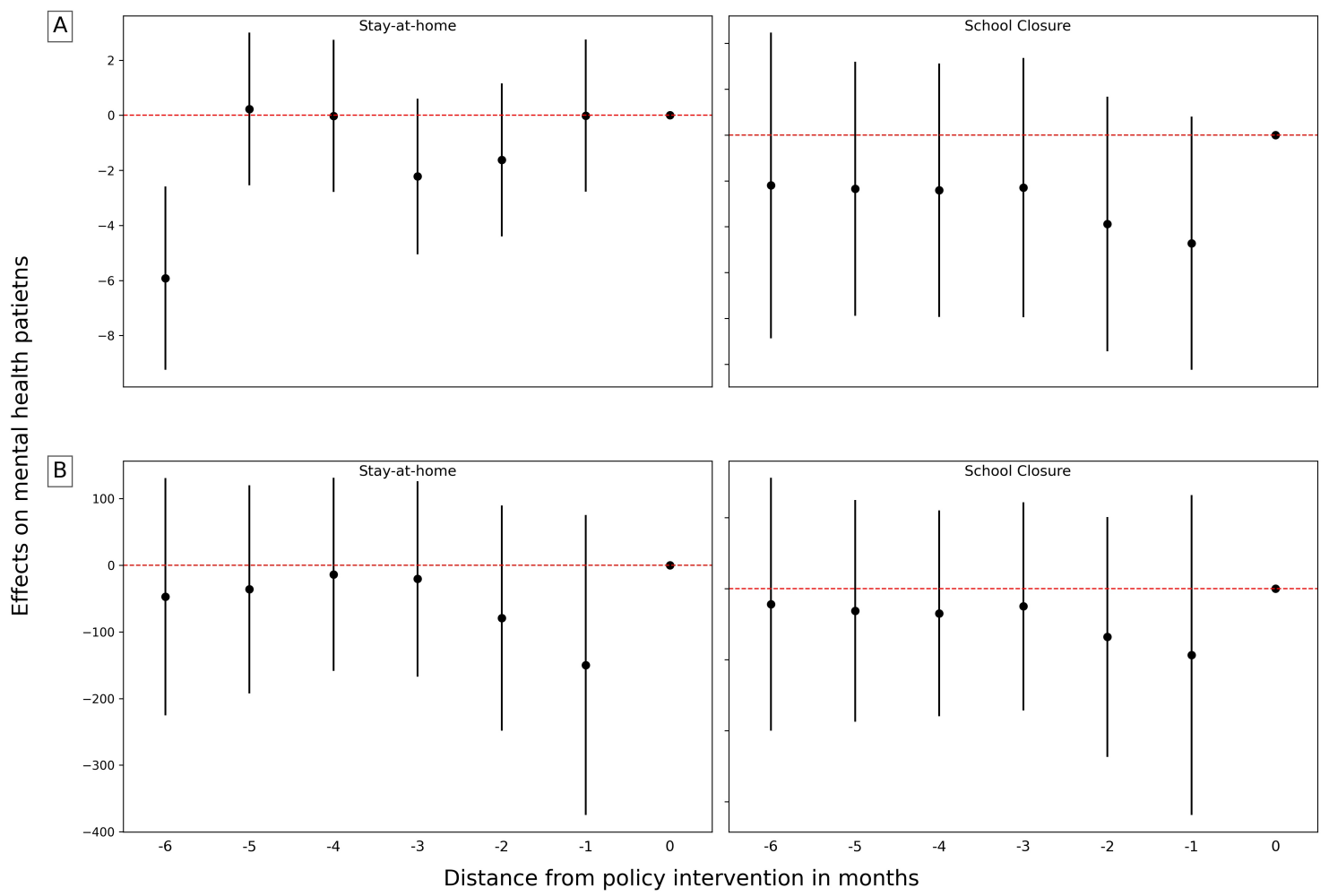

Figure 2: Event study of lockdowns effect (stay-at-home and school closure) in counties (A) and states (B) using 6-months pre-policy patients numbers as counterfactual. Coefficients are shown with their corresponding $95 \%$ confidence interval

\subsection{Parallel Trend Assumption}

To apply DID, first we must validate the pre-policy parallel trends assumption. We tested the equality of pre-policy trends for counties and states using Eq. 5 and Eq. 6 respectively. We plot the event-study coefficients for 6 months before policy implementation from the models of stay-at-home and school-closure 
medRxiv preprint doi: https://doi.org/10.1101/2021.05.26.21257598; this version posted June 2, 2021. The copyright holder for this preprint (which was not certified by peer review) is the author/funder, who has granted medRxiv a license to display the preprint in perpetuity. It is made available under a CC-BY-NC-ND 4.0 International license .

orders and the corresponding $95 \%$ confidence intervals. Figure 2 shows that the event-study coefficients are generally non-significant, therefore we cannot reject the null hypothesis of parallel trends. Accordingly, the key assumption of parallel trends of DID is satisfied for both counties and states.

\subsection{Effects on Mental Health Patients}

We consider mental health patients for the causal DID inference model from September 1, 2019 to December 31, 2020 to allow us to observe prolonged effects since mental health disorders may appear some time after a trauma [6]. In Tables B.4 and B.5 in the appendix we summarize the estimated effects based on Eq. 1 and Eq. 2 of stay-at-home and school closure lockdowns on the mental health in counties and states respectively for different population groups with the adjusted results after controlling for COVID-19 cases. Along with regression estimates, we include significance measures of p-value, $95 \%$ confidence intervals of standard errors, and R-squared $\left(R^{2}\right)$.

We selected COVID-19 confirmed cases to be a confounding effect and adjusted the regression models using TVA model of Eq. 3 and Eq. 4. Figure 3 confirms COVID-19 effect on mental health patients with significant correlation between both populations $\left(\mathrm{R}^{2}=0.77\right.$, p-value $\left.<2 \times 10^{-16}\right)$.

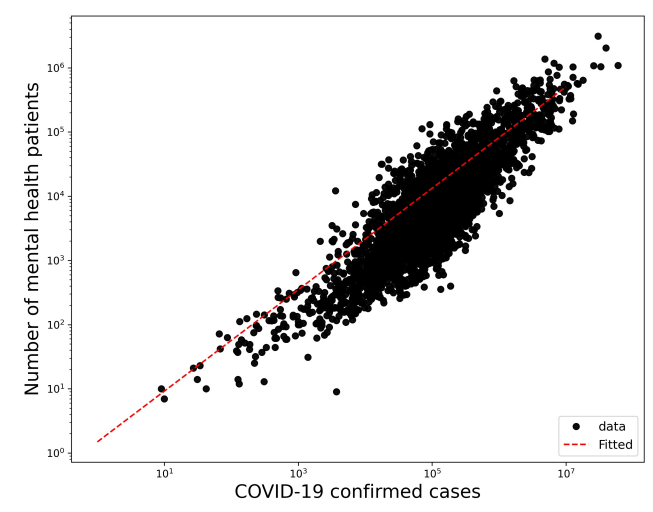

Figure 3: Correlation of mental health patients and COVID-19 confirmed cases in a log-log plot with an increase of 0.043 mental health patients for each confirmed COVID-19 case in counties $\left(\mathrm{R}^{2}=0.77\right.$, $\mathrm{p}$-value $<$ $\left.2 \times 10^{-16}\right)$

Tables B.6 and B.7 in the appendix summarize the estimated effects of Eq. 1 and Eq. 2 at different periods of time $z$ where $z=\{1,5,9\}$-months after lockdowns, to show the dynamic effect of stay-at-home and school closures in counties and states respectively.

Figures 4 and 5 show the average differences of mental health patients between counties with lockdown and without lockdown, for stay-at-home and school closure orders respectively. Similarly, Figures A.2 and A.3 in the appendix show the average differences at state-level.

We will further discuss results for each population group in both counties and states.

\subsubsection{Effects on Total Mental Health}

Based on Table B.4 there is a significant positive effect of stay-at-home order across counties on the total number of mental health patients, with a mean difference of 9.79 patients between counties with stay-athome orders and counties without. On average, mental health patients increased by $18.7 \%$ but declined by $1 \%$ in counties without lockdown (Figure 4 . Adjusting for COVID-19 confounding effect preserves the positive effect significant on mental health patient population with a lower effect size of 3.81 estimated mean difference (Table B.4). School closure has also a significant, but lower effect on mental health patient 
population (estimated mean difference $=2.35$ ), with percentage increase of $17 \%$ and $16 \%$ in counties with closed schools and without respectively (Figure 5), with no significant effect while adjusted for COVID-19 cases.

Similar results are found at the state-level, Table B.5 shows that the effect of stay-at-home order is positively significant for total mental health patients (difference estimate is 466.62 and 439.2 when adjusted) with $22 \%$ increase by December 2020 as compared to less than $2 \%$ increase in states without lockdown (Figure A.2). However, school closures have no significant effect at the state-level.

Table B.6 shows that the lockdown effect size keeps increasing from the first month after the lockdown date until the end of year 2020, for both stay-at-home orders and school closures in counties (Table B.6) and states (Table B.7).

\subsubsection{Gender Effects}

In counties, the estimated effect of stay-at-home orders on both females and males are 7.32 (3.32 when adjusted) and 3.68 (1.3 when adjusted) respectively (Table B.4). Female patients increased by $24 \%$ in counties with stay-at-home orders in comparison with $3 \%$ in counties without (Figure 4). Male patients declined by $5 \%$ in counties without stay-at-home orders. The estimated effect of school closures is significant for females (mean difference $=2.21$, and 0.77 when adjusted), but not significant for males (Table B.4).

Similarly in states, the estimated mean difference for females is 322.9 (292.37 when adjusted) and for males is 144.1 (187.27 when adjusted) (Table B.5. Female patients increased by $29 \%$ and $6 \%$ in states with stay-at-home orders and without respectively, while male patient numbers decreased in states without stay-at-home lockdown (Figure A.2). Similarly, school closures caused significant effect on female patients (estimation $=113.61$ and not significant when adjusted) but the effect is not significant on male patients (Table B.5)

The effect of both lockdowns on female and male patients kept increasing significantly throughout the year of 2020 in counties and states (Tables B.6. B.7)

\subsubsection{Diagnosis Effects}

We selected top five mental disorders (e.g. panic disorder) that peaked in 2020, and other disorders of interest (insomnia and life management difficulty) to investigate the effect of lockdowns on patient populations for specific diagnosis.

In counties, all disorders were positively and significantly affected by stay-at-home orders and mostly by school closures with lower effect sizes. Patients diagnosed with panic disorder (ICD-10: F41) had the largest difference effect among other mental illnesses and increased in both county groups (31.8\% vs 8.88\%) with estimated effect of 4.06 (1.51 when adjusted). Patients with attention-deficit hyperactivity disorder (ICD-10: F90) decreased in counties without stay-at-home order by $-13.6 \%$ with estimated effect of 1.78 (1.55 when adjusted). Patients diagnosed with life management difficulty (ICD-10: Z73) (i.e. burnout) doubled in counties with stay-at-home orders, compared to $10 \%$ increase in counties without such lockdown with estimated effect 1.34 (1.55 when adjusted) (Figure 4). Unlikely, patients with insomnia, with significant estimated effect of -0.09 when adjusted, increased more in counties without school closures by $24 \%$ compared to $17 \%$ in counties with closures. Patients diagnosed with life management difficulty disorder increased more in counties without school closures by $127.85 \%$ compared with $94.64 \%$ with closures, and the estimated effect is -5.14 and not significant when adjusted (Table B.4 and Figure 5).

Similarly at the state-level, panic disorder (ICD-10: F41) increased by $38.4 \%$ in states with stay-at-home orders (Figure A.2) and had the largest difference effect size with mean difference of 170.8 and 136.75 when adjusted (Table|B.5). Patients with life management difficulty increased more in states without a school closure by $161.49 \%$ compared to $123.36 \%$ in states with closures with estimated effects of -14.35 and -14.88 when adjusted.

Over time, the effect of stay-at-home order kept increasing significantly for all selected mental disorders across counties (Table B.6) and states (Table B.7). While school closure effect is significantly increasing for most diagnosis except for life management difficulty diagnosis where the effect kept declining. 


\subsubsection{Age Effects}

At the county-level, for most age groups, both lockdowns have positive significant effects on mental health patient population, except the eldest age group ( $>80 \mathrm{yrs}$ old), which showed a negative effect. Based on Table B.4 the two largest significant differences were for adults between 31 and 40 years old and adults between 21 and 30 years old. Adults in their thirties increased by $20.47 \%$ in counties with stay-at-home order but declined by $-0.1 \%$ in counties without, with mean difference of 3.52 (1.74 when adjusted). Adults in their twenties increased more in counties with stay-at-home orders by $30.01 \%$ compared to $11 \%$ in counties without, with estimated effect of 3.39 (1.3 when adjusted). Young patients under 11 and adolescent patients under 21 decreased in counties without stay-at-home orders by $-1.2 \%$ and $-4.5 \%$ respectively. The estimated effect for children under 11 is 1.09, but not significant when adjusted, and for adolescents (11 to 20) is 2.08 and 0.7 when adjusted (Figure 4 ).

Similarly, school closures affected patients in their thirties but with lower mean differences of 0.88 (not significant when adjusted) (Table B.5). They increased by 18.75 vs. 18.62 in both regions with and without closures respectively. While Teenager and adolescent (11 to 20) patients increased more in counties with school closures by $27.16 \%$, compared to $19.17 \%$ in counties without closures, with estimated effect 0.6 (not significant when adjusted) (Figure 5p.

Similar observations are found at the state-level based on Table B.5. For most age groups both stay-athome and school closure orders show significant positive effect, with larger effect sizes for people aged less than 40 years old. Mental health patients who are in their thirties increased by $28 \%$ and $1 \%$ in states with stay-at-home order and without respectively. Similarly, patients in their twenties increased by $40 \%$ and $15 \%$ in states with stay-at-home order and without respectively (Figure A.2.

The effect size of both lockdowns on most age groups kept increasing significantly throughout the year of 2020. Children less than 11 years old had the largest change of estimation size, which indicates a greater effect on children appeared later on in counties with stay-at-home orders (Table B.6).

\section{Discussion}

Early in March 2020, governments around the world imposed non-pharmaceutical interventions, such as social distancing policies to contain the spread of COVID-19. Social distancing measures, such as shelter-in-place orders, which restrict people's movements, proved to reduce the number of COVID-19 cases and fatalities 16, 17, 8. However, mitigation policies come with costs and benefits, which may be further analyzed to help determine the optimal time to release or stop a policy intervention [26. Prior research did not investigate the causal relation between COVID-19 mitigation policies and population-level mental health. Although much evidence showed significant mental health degradation associated with COVID-19 pandemic [13, 20, 2, 5, 14, the causal relation of lockdown for a longer period of time had not been investigated. In our study, we used large-scale medical claims data to estimate the effects of lockdowns on mental health patient population at the state- and county-levels in the United States.

Results from our DID model demonstrate a statistically significant causal effect of lockdown measures (stay-at-home and school closure orders) on the increasing population of mental health patients in 2020. Further, results emphasize the cost brought by extra months of lockdowns, in which effect sizes keep increasing until the end of 2020 .

A main limitation of our study that impacts representativeness of results is that our medical claims data does not cover Medicare and Medicaid health insurance programs. Medicare covers most aged and disabled population across the US, while Medicare covers a wider range of population including low-income beneficiaries covering $30 \%$ of US population [25. Hence, our data misses some population groups in the US.

Despite the limitation of the data, our findings provide important policy implications. There is a significant mental health cost for non-pharmaceutical interventions, especially interventions that are extended to a long duration of time with no expected time for lifting. Our results suggest that policymakers should take into consideration the mental health cost and ensure mental health treatment capacity.

Furthermore, we showed that number of patients had dropped right after lockdowns and then progres- 
medRxiv preprint doi: https://doi.org/10.1101/2021.05.26.21257598; this version posted June 2, 2021. The copyright holder for this preprint (which was not certified by peer review) is the author/funder, who has granted medRxiv a license to display the preprint in perpetuity.

It is made available under a CC-BY-NC-ND 4.0 International license .

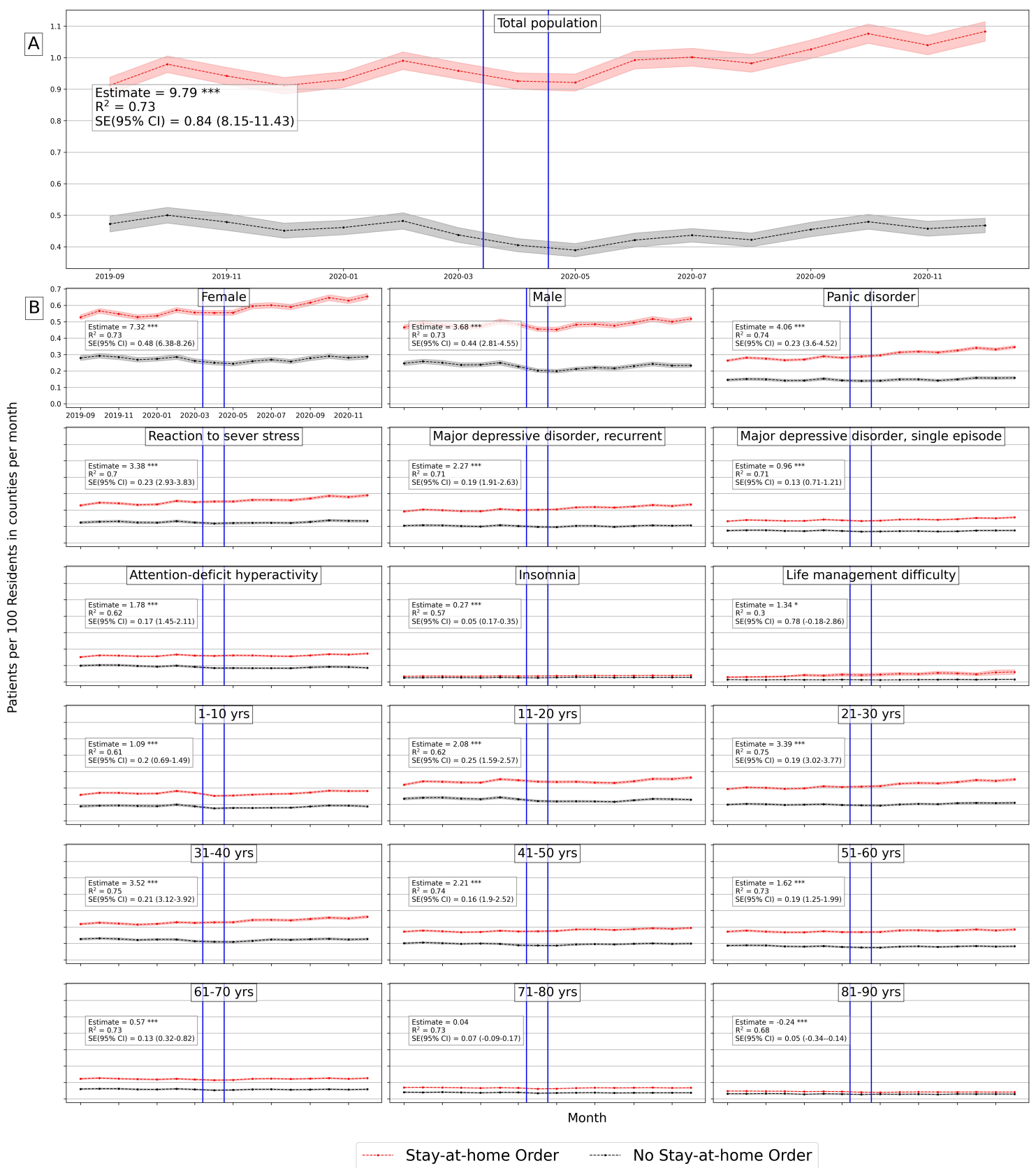

Figure 4: Average number of mental health patients over time (September 2019 - December 2020) in counties with stay-at-home orders and without. Vertical lines show the first stay-at-home order on 3/14/2020 and last 0n 4/07/2020 across United States. Difference-in-differences estimates are included for each population. (Detailed average percentage changes are listed in Table B.2.

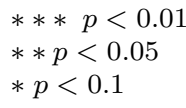

sively increased in June and July 2020, which suggest that people with mental health afflictions did not have the ability to seek care directly during restrictive lockdowns. Our results suggest that policy interventions 
medRxiv preprint doi: https://doi.org/10.1101/2021.05.26.21257598; this version posted June 2, 2021. The copyright holder for this preprint (which was not certified by peer review) is the author/funder, who has granted medRxiv a license to display the preprint in perpetuity.

It is made available under a CC-BY-NC-ND 4.0 International license .

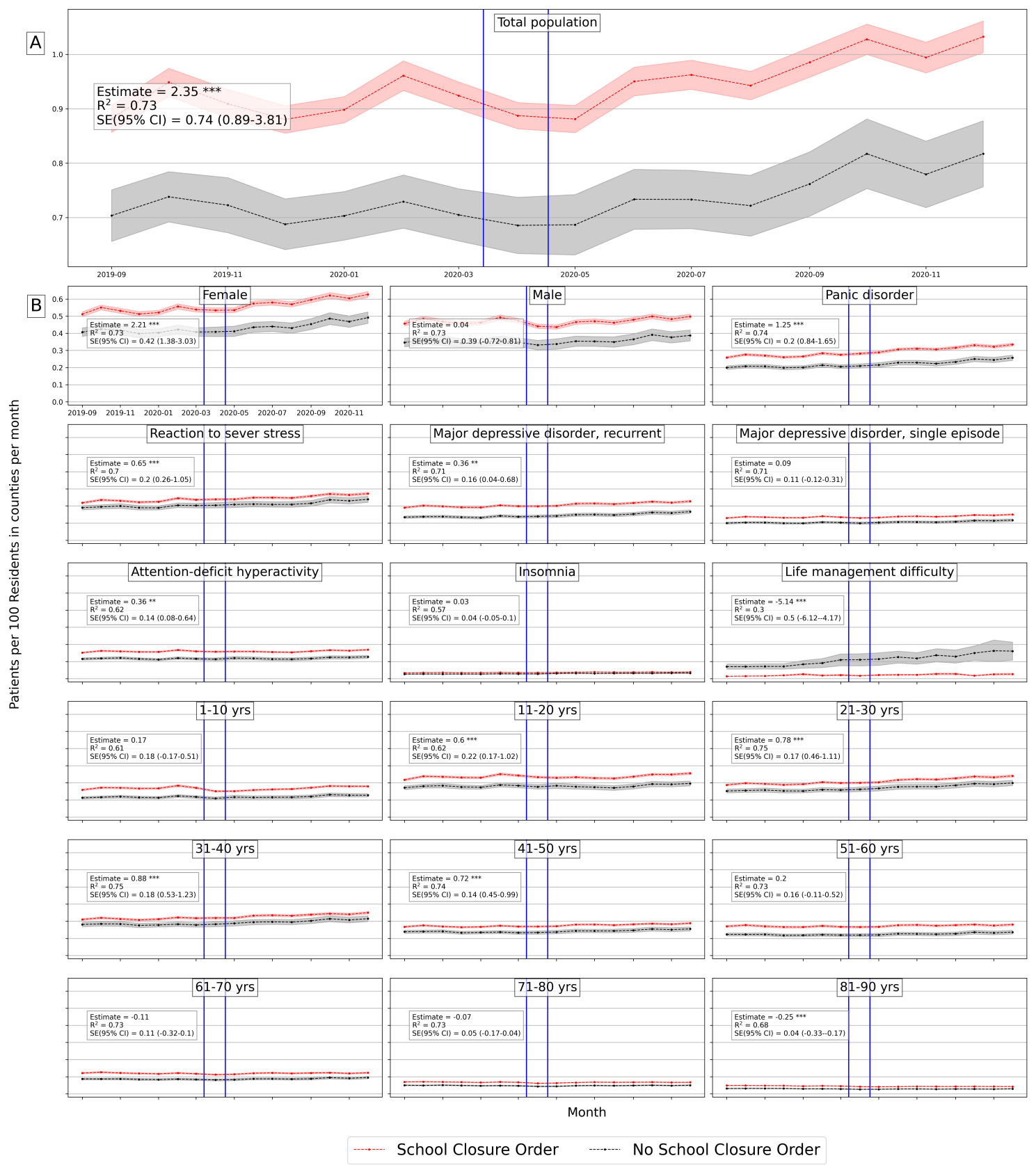

Figure 5: Average number of mental health patients over time (September 2019 - December 2020) in counties with school closure orders and without. Vertical lines show the first school closure on 3/10/2020 and last on 4/28/2020 across United States. Difference-in-differences estimates are included for each population group. (Detailed average percentage changes are listed in Table B.2

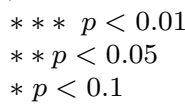

should be accompanied with strategies that allow seeking psychiatric help despite restrictive lockdowns, in order to avoid the exacerbated effect of delayed mental health treatment. 
medRxiv preprint doi: https://doi.org/10.1101/2021.05.26.21257598; this version posted June 2, 2021. The copyright holder for this preprint

(which was not certified by peer review) is the author/funder, who has granted medRxiv a license to display the preprint in perpetuity.

It is made available under a CC-BY-NC-ND 4.0 International license .

\section{Acknowledgment}

We thank the Change Healthcare team, Craig Midgett, Mina Atia, Andrew Harris, Anil Konda, Tim Suther, and Jaideep Kulkarni for facilitating our access to medical claims data and for their help in large-scale analysis.

\section{References}

[1] Alison Abbott. COVID's mental-health toll: How scientists are tracking a surge in depression. Nature, 590(7845), February 2021.

[2] Abi Adams-Prassl, Teodora Boneva, Marta Golin, and Christopher Rauh. The impact of the coronavirus lockdown on mental health: Evidence from the US. Cambridge Working Papers in Economics 2037, May 2020.

[3] Roy M. Anderson, Hans Heesterbeek, Don Klinkenberg, and T. Déirdre Hollingsworth. How will countrybased mitigation measures influence the course of the COVID-19 epidemic? The Lancet, 395(10228):931934, March 2020.

[4] Joshua D. Angrist and Jörn-Steffen Pischke. Mostly Harmless Econometrics: An Empiricist's Companion. December 2008.

[5] Abel Brodeur, Andrew E. Clark, Sarah Fleched, and Nattavudh Powdthavee. COVID-19, lockdowns and well-being: Evidence from Google Trends. Journal of Public Economics, 193:104346, January 2021.

[6] Samantha K. Brooks, Rebecca K. Webster, Louise E. Smith, Lisa Woodlan, Simon Wessely, Neil Greenberg, and Gideon James Rubin. The psychological impact of quarantine and how to reduce it: rapid review of the evidence. The Lancent, 395(10227):912-920, March 2020.

[7] Vera Clemens, Peter Deschamps, Jörg M. Fegert, Dimitris Anagnostopoulos, Sue Bailey, Maeve Doyle, Stephan Eliez, Anna Sofie Hansen, Johannes Hebebrand, Manon Hillegers, Brian Jacobs, Andreas Karwautz, Eniko Kiss, Konstantinos Kotsis, Hojka Gregoric Kumperscak, Milica Pejovic-Milovancevic, Anne Marie Røaberg Christensen, Jean-Philippe Raynaud, Hannu Westerinen, and Piret VisnapuuBernadt. Potential efects of "social" distancing measures and school lockdown on child and adolescent mental health. European Child \& Adolescent Psychiatry, 29(6):739-742, June 2020.

[8] Domenico Cucinotta and Vanelli Maurizio. WHO declares COVID-19 a pandemic. Acta bio-medica, 91(1):157-160, March 2020.

[9] W. Cullen, G. Gulati, and B. D. Kelly. Mental health in the COVID-19 pandemic. QJM: An International Journal of Medicine, 113(5):311-312, May 2020.

[10] Mark É. Czeisler, Rashon I. Lane, Emiko Petrosky, Joshua F. Wiley, Aleta Christensen, Rashid Njai, Matthew D. Weaver, Rebecca Robbins, Elise R. Facer-Childs, Laura K. Barger, Charles A. Czeisler, Mark E. Howard, and Shantha M. W. Rajaratnam. Mental health, substance use, and suicidal ideation during the COVID-19 pandemic - United States, June 24-30, 2020. Morbidity and Mortality Weekly Report 32, Centers for Disease Control and Prevention (CDC), August 2020.

[11] Srikant Devaraj and Pankaj C. Patel. Change in psychological distress in response to changes in reduced mobility during the early 2020 COVID-19 pandemic: Evidence of modest effects from the U.S. Social Science 83 Medicine, 270:113615, February 2021.

[12] Lu Dong and Jennifer Bouey. Public mental health crisis during COVID-19 pandemic, China. Emerging Infectious Diseases, 26(7):1616-1618, July 2020. 
medRxiv preprint doi: https://doi.org/10.1101/2021.05.26.21257598; this version posted June 2, 2021. The copyright holder for this preprint

(which was not certified by peer review) is the author/funder, who has granted medRxiv a license to display the preprint in perpetuity.

It is made available under a CC-BY-NC-ND 4.0 International license .

[13] Timon Elmer, Kieran Mepham, and Christoph Stadtfeld. Students under lockdown: Comparisons of students' social networks and mental health before and during the COVID-19 crisis in Switzerland. PLoS ONE, 15(7):e0236337, July 2020.

[14] Bita Fayaz Farkhad and Dolores Albarracín. Insights on the implications of COVID-19 mitigation measures for mental health. Economics $\& 3$ Human Biology, 40:100963, January 2021.

[15] Thom File and Mathew Marlay. Living alone has more impact on mental health of young adults than older adults, January 2021. United States Census Bureau.

[16] James H. Fowler, Seth J. Hill, Remy Levin, and Nick Obradovich. The effect of stay-at-home orders on COVID-19 cases and fatalities in the United States. medRxiv 2020.04.13.20063628., April 2020.

[17] Andrew I. Friedson, Drew McNichols, Joseph J. Sabia, and Dhaval Dave. Did California's shelterin-place order work? early coronavirus-related public health effects. Working Paper 26992, National Bureau of Economic Research, April 2020.

[18] Osea Giuntella, Kelly Hyde, Silvia Saccardo, and Sally Sadoff. Lifestyle and mental health disruptions during COVID-19. Proceedings of National Academy of Sciences of the United States of America, 118(9):e2016632118, March 2021.

[19] Andrew Goodman-Bacon and Jan Marcus. Using difference-in-differences to identify causal effects of COVID-19 policies. Survey Research Methods, 14(2):153-158, 2020.

[20] Maria Rosaria Gualano, Giuseppina Lo Moro, Gianluca Voglino, Fabrizio Bert, and Roberta Siliquini. Effects of Covid-19 lockdown on mental health and sleep disturbances in Italy. International Journal of Environmental Research and Public Health, 17(13):4779, June 2020.

[21] Ravi Gupta, Sandeep Grover, Aniruddha Basu, Vijay Krishnan, Adarsh Tripathi, Alka Subramanyam, Anil Nischal, Arshad Hussain, Aseem Mehra, Atul Ambekar, Gautam Saha, Kshirod Kumar Mishra, Manish Bathla, Mukesh Jagiwala, Narayana Manjunatha, Naresh Nebhinani, Navendu Gaur, Niraj Kumar, Pronob Kumar Dalal, Pankaj Kumar, Purav Kumar Midha, Ritu Daga, Sai Krishna Tikka, Samir Kumar Praharaj, Sandeep Kumar Goyal, Shweta Kanchan, Siddharth Sarkar, Sourav Das, Sujit Sarkhel, Susanta Kumar Padhy, Swapnajeet Sahoo, T. S. Satyanarayana Rao, Vaibhav Dubey, Vikas Menon, Vishal Chhabra, Vivekanand Lahan, and Ajit Avasthi. Changes in sleep pattern and sleep quality during COVID-19 lockdown. Indian Journal of Psychiatry, 62(4):370-378, July-August 2020.

[22] Kristin M. Holland, Christopher Jones, Alana M. Vivolo-Kantor, et al. Trends in US emergency department visits for mental health, overdose, and violence outcomes before and during the COVID-19 pandemic. JAMA Psychiatry, 78(4):372-379, February 2021.

[23] Luke J. Keele, Dylan S. Small, Jesse Y. Hsu, and Colin B. Fogarty. Patterns of effects and sensitivity analysis for differences-in-differences. arXiv:1901.01869 [stat.AP]., January 2019.

[24] Patrick Klaiber, Jin H. Wen, Anita DeLongis, and Nancy L. Sin. The ups and downs of daily life during COVID-19: Age differences in affect, stress, and positive events. The Journals of Gerontology. Series B, Psychological Sciences and Social Sciences, 76(2):e30-e37, February 2021.

[25] Barbara S. Klees, Eric T. Eckstein II, and Catherine A. Curtis. Brief summaries of Medicare \& Medicaid. Summary report, Centers for Medicare Medicaid Services, Department of Health and Human Services, November 2020.

[26] Richard Layard, Andrew Clark, Jan-Emmanuel De Neve, Christian Krekel, Daisy Fancourt, Nancy Hey, and Gus O'Donnell. When to release the lockdown? a wellbeing framework for analysing costs and benefits. IZA Discussion Papers 13186, Institute of Labor Economics (IZA), April 2020. 
medRxiv preprint doi: https://doi.org/10.1101/2021.05.26.21257598; this version posted June 2, 2021. The copyright holder for this preprint

(which was not certified by peer review) is the author/funder, who has granted medRxiv a license to display the preprint in perpetuity.

It is made available under a CC-BY-NC-ND 4.0 International license .

[27] Minha Lee, Jun Zhao, Qianqian Sun, Yixuan Pan, Weiyi Zhou, Chenfeng Xiong, and Lei Zhang. Human mobility trends during the early stage of the COVID-19 pandemic in the United States. PLoS ONE, 15(11):1-15, November 2020.

[28] Rebecca T. Leeb, Rebecca H. Bitsko, Lakshmi Radhakrishnan, Pedro Martinez, Rashid Njai, and Kristin M. Holland. Mental health-related emergency department visits among children aged $<18$ years during the COVID-19 pandemic — United States, January 1-October 17, 2020. Morbidity and Mortality Weekly Report, Centers for Disease Control and Prevention (CDC), November 2020.

[29] Osnat C. Melamed, Margaret K. Hahn, Sri Mahavir Agarwal, Valerie H. Taylor, Benoit H. Mulsant, and Peter Selby. Physical health among people with serious mental illness in the face of COVID-19: Concerns and mitigation strategies. General Hospital Psychiatry, 66:30-33, September-October 2020.

[30] Geofrey Musinguzi and Benedict Oppong Asamoah. The Science of Social Distancing and Total Lock Down: Does it work? whom does it benefit? Electronic Journal of General Medicine, 17(6):em230, April 2020.

[31] Scott A. Paluska and Thomas L. Schwenk. Physical activity and mental health. Sports Medicine, 29(3):167-180, March 2000.

[32] Sadiq Y. Patel, Ateev Mehrotra, Haiden A. Huskamp, Lori Uscher-Pines, Ishani Ganguli, and Michael L. Barnett. Trends in outpatient care delivery and telemedicine during the COVID-19 pandemic in the US. JAMA Internal Medicine, 181(3):388-391, November 2020.

[33] Betty Pfefferbaum and Carol S. North. Mental health and the Covid-19 pandemic. The New England Journal of Medicine, 383:510-512, August 2020.

[34] Ravi Philip Rajkumar. COVID-19 and mental health: A review of the existing literature. Asian Journal of Psychiaty, 52:102066, August 2020.

[35] Ashesh Rambachan and Jonathan Roth. An honest approach to parallel trends, November 2020. unpublished.

[36] Martin J. Sliwinski, Sara Freed, Stacey B. Scott, Giancarlo Pasquini, and Joshua M. Smyth. Does chronic stress moderate age differences in emotional well-being? testing predictions of strength and vulnerability integration. The Journals of Gerontology. Series B, Psychological Sciences and Social Sciences. to appear.

[37] Amy B. Sullivan, Alexa Kane, Alicia J. Roth, Bryan E. Davis, Michelle L. Drerup, and Leslie J. Heinberg. The COVID-19 crisis: A mental health perspective and response using telemedicine. Journal of Patient Experience, 7(3):295-301, July 2020.

[38] Lindsay A. Taliaferro, Barbara A. Rienzo, R. Morgan Pigg, M. David Miller, and Virginia J. Dodd. Associations between physical activity and reduced rates of hopelessness, depression, and suicidal behavior among college students. Journal of American College Health, 57(4):427-436, 2010.

[39] Linda Thunström, Stephen C. Newbold, David Finnoff, Madison Ashworth, and Jason F. Shogren. The benefits and costs of using social distancing to flatten the curve for COVID-19. Journal of Benefit-Cost Analysis, 11(2):179-195, Summer 2020.

[40] The New York Times. Coronavirus (Covid-19) data in the United States, 2021. dataset.

[41] Jeff Trinkl and Alejandro Muñoz del Río. Effect of COVID-19 pandemic on visit patterns for anxiety and depression. Epic Health Research Network, August 2020.

[42] Lori Uscher-Pines, Jessica Sousa, Ateev Mehrotra Pushpa Raja, Michael L. Barnett, and Haiden A. Huskamp. Suddenly becoming a "virtual doctor": Experiences of psychiatrists transitioning to telemedicine during the COVID-19 pandemic. Psychiatric Services, 71(11):1143-1150, September 2020. 
medRxiv preprint doi: https://doi.org/10.1101/2021.05.26.21257598; this version posted June 2, 2021. The copyright holder for this preprint (which was not certified by peer review) is the author/funder, who has granted medRxiv a license to display the preprint in perpetuity.

It is made available under a CC-BY-NC-ND 4.0 International license .

[43] Sofia B. Villas-Boas, James Sears, Miguel Villas-Boas, and Vasco Villas-Boas. Are we \#StayingHome to flatten the curve? CUDARE working papers, UC Berkeley: Department of Agricultural and Resource Economics, April 2020.

[44] Marielle Wathelet, Stéphane Duhem, Guillaume Vaiva, Thierry Baubet, Enguerrand Habran, Emilie Veerapa, Christophe Debien, Sylvie Molenda, Mathilde Horn, Pierre Grandgenèvre, Charles-Edouard Notredame, and Fabien D'Hondt. Factors associated with mental health disorders among university students in France confined during the COVID-19 pandemic. JAMA Network Open, 3(10):e2025591, October 2020.

[45] Han Xiao, Yan Zhang, Desheng Kong, Shiyue Li, and Ningxi Yang. The effects of social support on sleep quality of medical staff treating patients with coronavirus disease 2019 (COVID-19) in January and February 2020 in China. Medical Science Monitor, 26(e923549):1-8, March 2020.

[46] Bret Zeldow and Laura A. Hatfield. Confounding and regression adjustment in difference-in-differences. arXiv:1911.12185 [stat.AP]., November 2019.

[47] Yuncheng Zhu, Liangliang Chen, Haifeng Ji, Maomao Xi, Yiru Fang, and Yi Li. The risk and prevention of novel coronavirus pneumonia infections among inpatients in psychiatric hospitals. Neuroscience Bulletin, 36(3):299-302, March 2020.

\section{A Supplementary Figures}

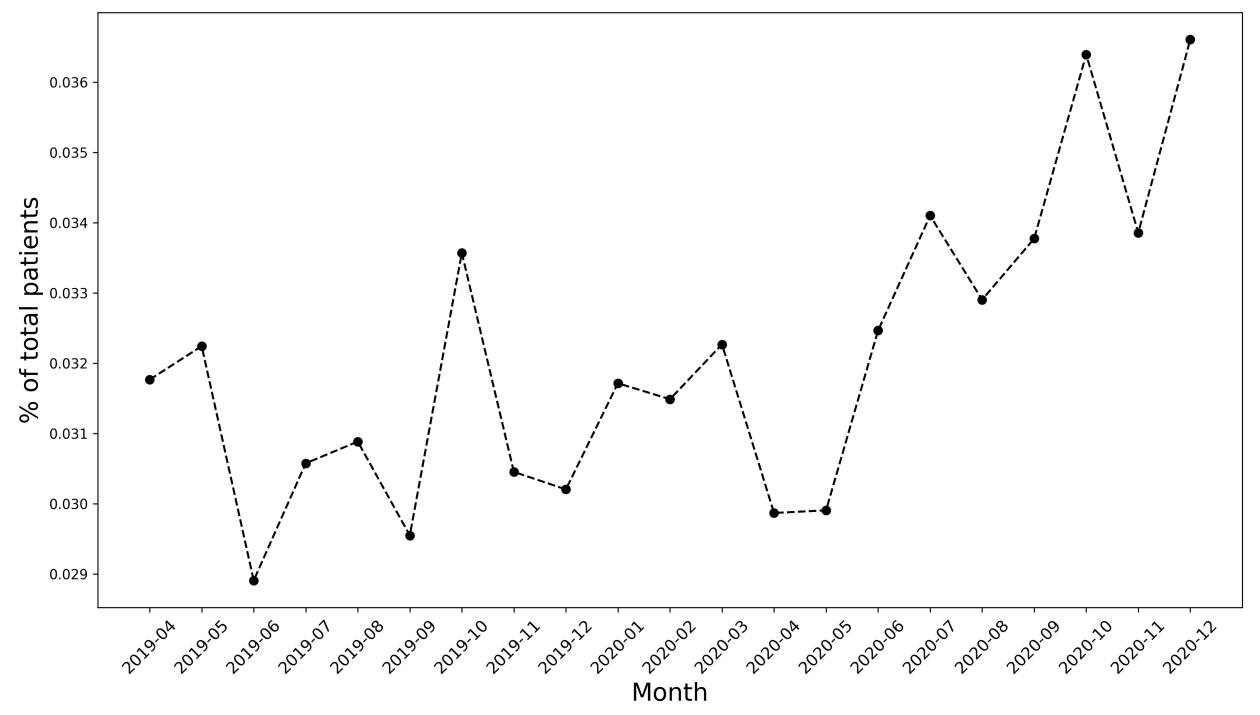

Figure A.1: Mental health patients over time

\section{B Supplementary Tables}


medRxiv preprint doi: https://doi.org/10.1101/2021.05.26.21257598; this version posted June 2, 2021. The copyright holder for this preprint (which was not certified by peer review) is the author/funder, who has granted medRxiv a license to display the preprint in perpetuity.

It is made available under a CC-BY-NC-ND 4.0 International license .

Table B.1: Percentage change between 2019 and 2020 mental health patients among population groups

\begin{tabular}{l|c}
\hline Group & Change \\
\hline Total Population & $22 \%$ \\
Female & $20 \%$ \\
Male & $14 \%$ \\
Panic disorder & $33 \%$ \\
Reaction to sever stress & $31 \%$ \\
Major depressive disorder, recurrent & $25 \%$ \\
Major depressive disorder, single episode & $24 \%$ \\
Attention-deficit hyperactivity & $19 \%$ \\
Insomnia & $45 \%$ \\
Life management difficulty & $73 \%$ \\
$1-10$ yrs & $28 \%$ \\
$11-20$ yrs & $20 \%$ \\
$21-30$ yrs & $28 \%$ \\
$31-40$ yrs & $24 \%$ \\
$41-50$ yrs & $20 \%$ \\
$51-60$ yrs & $17 \%$ \\
$61-70$ yrs & $15 \%$ \\
$71-80$ yrs & $16 \%$ \\
$81-90$ yrs & $6 \%$ \\
\hline
\end{tabular}

Table B.2: (Supplement table for Figures 4 and 5). Percentage change of monthly average mental health population in counties with and without lockdowns between early September 2019 to end of December 2020

\begin{tabular}{l|rr|rr}
\hline \multirow{2}{*}{ Group } & \multicolumn{2}{|c|}{ Stay-at-home } & \multicolumn{2}{c}{ School Closure } \\
\cline { 2 - 5 } & No lockdown & Lockdown & No lockdown & Lockdown \\
\hline Total Population & $-1.01 \%$ & $18.73 \%$ & $16.16 \%$ & $17.09 \%$ \\
Female & $2.88 \%$ & $24.13 \%$ & $20.89 \%$ & $22.53 \%$ \\
Male & $-5.33 \%$ & $11.05 \%$ & $11.88 \%$ & $9.06 \%$ \\
Panic disorder & $8.88 \%$ & $31.18 \%$ & $28.49 \%$ & $29.17 \%$ \\
Reaction to sever stress & $7.35 \%$ & $26.86 \%$ & $25.82 \%$ & $24.83 \%$ \\
Major depressive disorder, & $1.95 \%$ & $22.29 \%$ & $23.97 \%$ & $19.63 \%$ \\
recurrent & & & & \\
Major depressive disorder, & $1.02 \%$ & $18.00 \%$ & $17.10 \%$ & $16.10 \%$ \\
single episode & & & & \\
Attention-deficit hyperactivity & $-13.66 \%$ & $14.04 \%$ & $10.83 \%$ & $11.28 \%$ \\
Insomnia & $10.99 \%$ & $19.29 \%$ & $24.08 \%$ & $17.49 \%$ \\
Life management difficulty & $10.24 \%$ & $111.76 \%$ & $127.85 \%$ & $94.64 \%$ \\
$1-10$ yrs & $-1.17 \%$ & $14.84 \%$ & $13.19 \%$ & $13.09 \%$ \\
$11-20$ yrs & $-4.54 \%$ & $19.85 \%$ & $14.70 \%$ & $17.63 \%$ \\
$21-30$ yrs & $10.93 \%$ & $30.01 \%$ & $30.79 \%$ & $27.95 \%$ \\
$31-40$ yrs & $-0.10 \%$ & $20.47 \%$ & $18.62 \%$ & $18.75 \%$ \\
$41-50$ yrs & $-1.42 \%$ & $13.57 \%$ & $11.91 \%$ & $12.55 \%$ \\
$51-60$ yrs & $-5.16 \%$ & $7.68 \%$ & $10.69 \%$ & $6.13 \%$ \\
$61-70$ yrs & $-2.95 \%$ & $2.89 \%$ & $9.37 \%$ & $1.60 \%$ \\
$71-80$ yrs & $-8.34 \%$ & $-2.75 \%$ & $-0.29 \%$ & $-3.68 \%$ \\
$81-90$ yrs & $-6.41 \%$ & $-12.00 \%$ & $-5.02 \%$ & $-12.88 \%$ \\
\hline
\end{tabular}


medRxiv preprint doi: https://doi.org/10.1101/2021.05.26.21257598; this version posted June 2, 2021. The copyright holder for this preprint (which was not certified by peer review) is the author/funder, who has granted medRxiv a license to display the preprint in perpetuity.

It is made available under a CC-BY-NC-ND 4.0 International license .

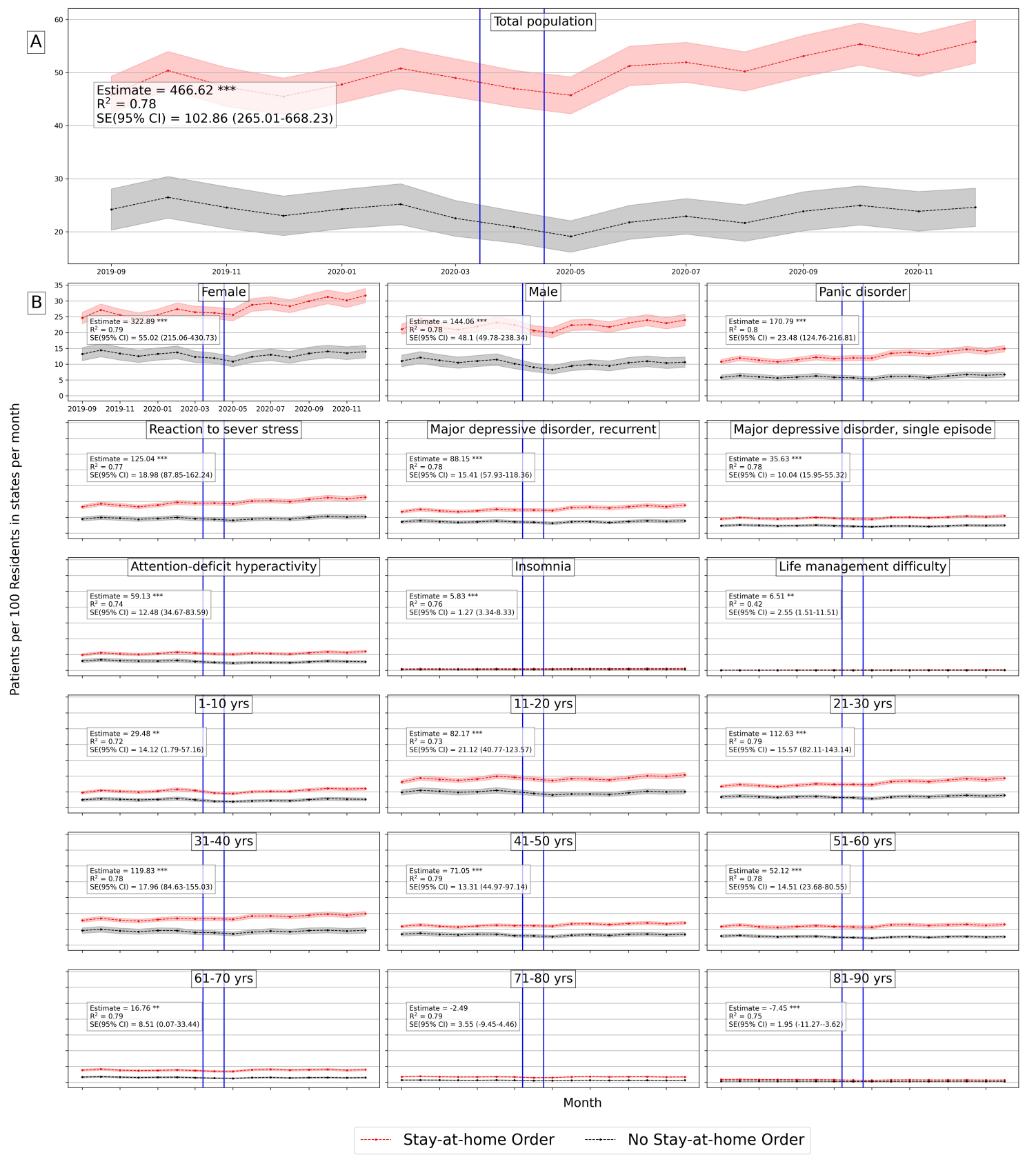

Figure A.2: Average number of mental health patients over time (September 2019 - December 2020) in states with stay-at-home orders and without. Vertical lines show the first stay-at-home order on 3/14/2020 and last 0n 4/07/2020 across United States. Difference-in-differences estimates are included for each population group. (Detailed average percentage changes are listed in Table B.3

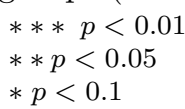


medRxiv preprint doi: https://doi.org/10.1101/2021.05.26.21257598; this version posted June 2, 2021. The copyright holder for this preprint (which was not certified by peer review) is the author/funder, who has granted medRxiv a license to display the preprint in perpetuity.

It is made available under a CC-BY-NC-ND 4.0 International license .

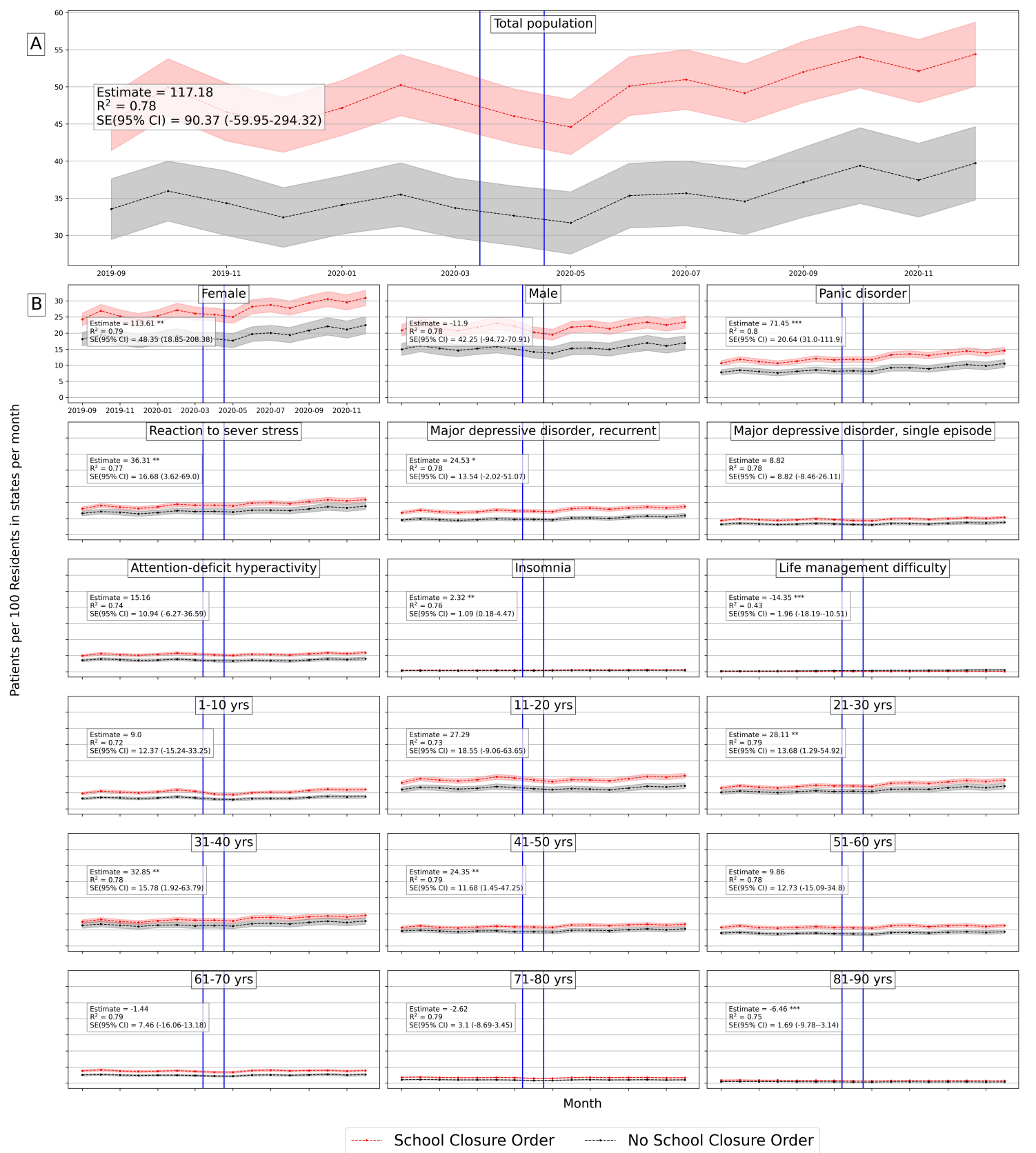

Figure A.3: Average number of mental health patients over time (September 2019 - December 2020) in states with school closure orders and without. Vertical lines show the first school closure on 3/10/2020 and last on 4/28/2020 across United States. Difference-in-differences estimates are included for each population group. (Detailed average percentage changes are listed in Table B.3)

\footnotetext{
$* * * p<0.01$

$* * p<0.05$

$* p<0.1$
} 
Table B.3: (Supplement table for Figures A.2 and A.3). Percentage change of monthly average mental health population in states with and without lockdowns between early September 2019 to end of December 2020

\begin{tabular}{l|rr|rr}
\hline \multirow{2}{*}{ Group } & \multicolumn{2}{|c|}{ Stay-at-home } & \multicolumn{2}{c}{ School Closure } \\
\cline { 2 - 5 } & No lockdown & Lockdown & No lockdown & Lockdown \\
\hline Total Population & $1.67 \%$ & $21.87 \%$ & $18.40 \%$ & $20.45 \%$ \\
Female & $5.91 \%$ & $28.86 \%$ & $24.00 \%$ & $27.42 \%$ \\
Male & $-3.42 \%$ & $13.93 \%$ & $13.10 \%$ & $12.24 \%$ \\
Panic disorder & $15.80 \%$ & $38.38 \%$ & $35.25 \%$ & $36.56 \%$ \\
Reaction to sever stress & $15.64 \%$ & $36.83 \%$ & $34.08 \%$ & $35.07 \%$ \\
Major depressive disorder, & $9.38 \%$ & $30.51 \%$ & $31.34 \%$ & $28.07 \%$ \\
recurrent & & & & \\
Major depressive disorder, & $6.29 \%$ & $22.95 \%$ & $19.62 \%$ & $21.89 \%$ \\
single episode & & & & \\
Attention-deficit hyperactivity & $-9.85 \%$ & $21.57 \%$ & $13.74 \%$ & $19.47 \%$ \\
Insomnia & $23.07 \%$ & $37.47 \%$ & $39.43 \%$ & $35.55 \%$ \\
Life management difficulty & $12.20 \%$ & $145.77 \%$ & $161.49 \%$ & $123.36 \%$ \\
$1-10$ yrs & $6.21 \%$ & $26.91 \%$ & $18.26 \%$ & $26.29 \%$ \\
11-20 yrs & $4.11 \%$ & $28.00 \%$ & $19.17 \%$ & $27.16 \%$ \\
$21-30$ yrs & $15.48 \%$ & $39.28 \%$ & $36.46 \%$ & $37.37 \%$ \\
$31-40$ yrs & $1.36 \%$ & $27.60 \%$ & $21.55 \%$ & $25.93 \%$ \\
$41-50$ yrs & $-1.55 \%$ & $18.79 \%$ & $14.77 \%$ & $17.35 \%$ \\
$51-60$ yrs & $-7.41 \%$ & $11.48 \%$ & $10.75 \%$ & $9.75 \%$ \\
$61-70$ yrs & $-10.83 \%$ & $3.75 \%$ & $4.49 \%$ & $2.39 \%$ \\
$71-80$ yrs & $-10.55 \%$ & $-3.66 \%$ & $-2.05 \%$ & $-4.66 \%$ \\
$81-90$ yrs & $-15.99 \%$ & $-18.71 \%$ & $-16.15 \%$ & $-19.00 \%$ \\
\hline
\end{tabular}


Table B.4: Effects of lockdown interventions on mental health of different population groups in counties

\begin{tabular}{|c|c|c|c|c|c|c|c|}
\hline \multirow[t]{2}{*}{ Group } & \multirow[t]{2}{*}{ model } & \multicolumn{3}{|c|}{ Stay-at-home Order } & \multicolumn{3}{|c|}{ School Closure } \\
\hline & & Estimat & $\mathrm{SE}(95 \% \mathrm{CI})$ & $\mathrm{R}^{2}$ & Estimate & $\mathrm{SE}(95 \% \mathrm{CI})$ & $\mathrm{R}^{2}$ \\
\hline \multirow[t]{2}{*}{ Total Population } & Not Adjusted & $9.79 * * *$ & $0.84(8.15-11.43)$ & 0.73 & $2.35^{* * *}$ & $0.74(0.89-3.81)$ & 0.73 \\
\hline & TVA & $3.81 * * *$ & $0.76(2.33-5.3)$ & 0.78 & -0.11 & $0.68(-1.44-1.21)$ & 0.78 \\
\hline \multirow[t]{2}{*}{ Female } & Not Adjusted & $7.32 * * *$ & $0.48(6.38-8.26)$ & 0.73 & $2.21 * * *$ & $0.42(1.38-3.03)$ & 0.73 \\
\hline & TVA & $3.32 * * *$ & $0.43(2.47-4.17)$ & 0.78 & $0.77 *$ & $0.4(-0.0-1.55)$ & 0.77 \\
\hline \multirow[t]{2}{*}{ Male } & Not Adjusted & $3.68 * * *$ & $0.44(2.81-4.55)$ & 0.73 & 0.04 & $0.39(-0.72-0.81)$ & 0.73 \\
\hline & TVA & $1.35 * * *$ & $0.41(0.55-2.15)$ & 0.77 & 0.22 & $0.3(-0.37-0.82)$ & 0.77 \\
\hline \multirow[t]{2}{*}{ Panic disorder } & Not Adjusted & $4.06 * * *$ & $0.23(3.6-4.52)$ & 0.74 & $1.25 * * *$ & $0.2(0.84-1.65)$ & 0.74 \\
\hline & TVA & $1.51 * * *$ & $0.21(1.1-1.92)$ & 0.8 & 0.13 & $0.19(-0.24-0.5)$ & 0.78 \\
\hline \multirow[t]{2}{*}{ Reaction to sever stress } & Not Adjusted & $3.38 * * *$ & $0.23(2.93-3.83)$ & 0.7 & $0.65 * * *$ & $0.2(0.26-1.05)$ & 0.7 \\
\hline & TVA & $1.33 * * *$ & $0.21(0.92-1.75)$ & 0.74 & -0.15 & $0.19(-0.53-0.23)$ & 0.73 \\
\hline \multirow{2}{*}{$\begin{array}{l}\text { Major depressive disorder, } \\
\text { recurrent }\end{array}$} & Not Adjusted & $2.27 * * *$ & $0.19(1.91-2.63)$ & 0.71 & $0.36^{* *}$ & $0.16(0.04-0.68)$ & 0.71 \\
\hline & TVA & $0.73 * * *$ & $0.17(0.39-1.06)$ & 0.76 & $-0.35 * *$ & $0.15(-0.65-0.05)$ & 0.75 \\
\hline \multirow{2}{*}{$\begin{array}{l}\text { Major depressive disorder, } \\
\text { single episode }\end{array}$} & Not Adjusted & $0.96 * * *$ & $0.13(0.71-1.21)$ & 0.71 & 0.09 & $0.11(-0.12-0.31)$ & 0.71 \\
\hline & TVA & 0.16 & $0.12(-0.07-0.39)$ & 0.75 & $-0.2 *$ & $0.11(-0.41-0.01)$ & 0.73 \\
\hline \multirow[t]{2}{*}{ Attention-deficit hyperactivity } & Not Adjusted & $1.78 * * *$ & $0.17(1.45-2.11)$ & 0.62 & $0.36^{* *}$ & $0.14(0.08-0.64)$ & 0.62 \\
\hline & TVA & $0.95 * * *$ & $0.16(0.64-1.27)$ & 0.65 & 0.05 & $0.14(-0.22-0.32)$ & 0.65 \\
\hline \multirow[t]{2}{*}{ Insomnia } & Not Adjusted & $0.27 * * *$ & $0.05(0.17-0.35)$ & 0.57 & 0.03 & $0.04(-0.05-0.1)$ & 0.57 \\
\hline & TVA & $0.11 * *$ & $0.04(0.02-0.2)$ & 0.59 & $-0.09 * *$ & $0.04(-0.16-0.01)$ & 0.59 \\
\hline \multirow[t]{2}{*}{ Life management difficulty } & Not Adjusted & $1.34 *$ & $0.78(-0.18-2.86)$ & 0.3 & $-5.14 * * *$ & $0.5(-6.12-4.17)$ & 0.3 \\
\hline & TVA & $1.55 * *$ & $0.78(0.02-3.09)$ & 0.3 & $-5.09 * * *$ & $0.5(-6.08-4.11)$ & 0.3 \\
\hline \multirow[t]{2}{*}{$1-10 \mathrm{yrs}$} & Not Adjusted & $1.09 * * *$ & $0.2(0.69-1.49)$ & 0.61 & 0.17 & $0.18(-0.17-0.51)$ & 0.61 \\
\hline & TVA & 0.07 & $0.19(-0.31-0.45)$ & 0.66 & $-0.48 * * *$ & $0.15(-0.77-0.19)$ & 0.66 \\
\hline \multirow[t]{2}{*}{$11-20$ yrs } & Not Adjusted & $2.08 * * *$ & $0.25(1.59-2.57)$ & 0.62 & $0.6 * * *$ & $0.22(0.17-1.02)$ & 0.62 \\
\hline & TVA & $0.7 * * *$ & $0.24(0.24-1.16)$ & 0.66 & -0.17 & $0.18(-0.52-0.18)$ & 0.66 \\
\hline \multirow[t]{2}{*}{$21-30 \mathrm{yrs}$} & Not Adjusted & $3.39 * * *$ & $0.19(3.02-3.77)$ & 0.75 & $0.78^{* * *}$ & $0.17(0.46-1.11)$ & 0.75 \\
\hline & TVA & $1.3 * * *$ & $0.17(0.96-1.64)$ & 0.8 & $-0.61 * * *$ & $0.13(-0.87-0.35)$ & 0.8 \\
\hline \multirow[t]{2}{*}{$31-40$ yrs } & Not Adjusted & $3.52 * * *$ & $0.21(3.12-3.92)$ & 0.75 & $0.88^{* * *}$ & $0.18(0.53-1.23)$ & 0.75 \\
\hline & TVA & $1.74 * * *$ & $0.19(1.37-2.12)$ & 0.79 & 0.07 & $0.14(-0.22-0.35)$ & 0.79 \\
\hline \multirow[t]{2}{*}{$41-50$ yrs } & Not Adjusted & $2.21 * * *$ & $0.16(1.9-2.52)$ & 0.74 & $0.72 * * *$ & $0.14(0.45-0.99)$ & 0.74 \\
\hline & TVA & $1.13 * * *$ & $0.15(0.83-1.42)$ & 0.78 & 0.1 & $0.12(-0.12-0.33)$ & 0.78 \\
\hline \multirow[t]{2}{*}{$51-60$ yrs } & Not Adjusted & $1.62 * * *$ & $0.19(1.25-1.99)$ & 0.73 & 0.2 & $0.16(-0.11-0.52)$ & 0.73 \\
\hline & TVA & $0.66 * * *$ & $0.18(0.31-1.01)$ & 0.75 & -0.21 & $0.14(-0.48-0.06)$ & 0.75 \\
\hline \multirow[t]{2}{*}{$61-70$ yrs } & Not Adjusted & $0.57 * * *$ & $0.13(0.32-0.82)$ & 0.73 & -0.11 & $0.11(-0.32-0.1)$ & 0.73 \\
\hline & TVA & 0.1 & $0.12(-0.13-0.34)$ & 0.76 & -0.05 & $0.09(-0.22-0.13)$ & 0.76 \\
\hline \multirow[t]{2}{*}{$71-80$ yrs } & Not Adjusted & 0.04 & $0.07(-0.09-0.17)$ & 0.73 & -0.07 & $0.05(-0.17-0.04)$ & 0.73 \\
\hline & TVA & -0.08 & $0.06(-0.21-0.04)$ & 0.76 & 0.05 & $0.04(-0.04-0.13)$ & 0.76 \\
\hline \multirow[t]{2}{*}{$81-90$ yrs } & Not Adjusted & $-0.24 * * *$ & $0.05(-0.34-0.14)$ & 0.68 & $-0.25 * * *$ & $0.04(-0.33-0.17)$ & 0.68 \\
\hline & TVA & $-0.18 * * *$ & $0.05(-0.28-0.09)$ & 0.71 & $-0.15 * * *$ & $0.03(-0.22-0.09)$ & 0.71 \\
\hline
\end{tabular}

Notes: Each row represents two coefficients of two DID regression models, stay-at-home order and school closure regression models with raw total population in counties, with county and date as fixed effects using Eq. 1. We controlled for COVID-19 confirmed cases to adjust the models using Eq. 3 for the TVA model

$* * * p<0.01$

$* * p<0.05$

$* p<0.1$ 
Table B.5: Effects of lockdown interventions on mental health of different population groups in states

\begin{tabular}{|c|c|c|c|c|c|c|c|}
\hline \multirow[t]{2}{*}{ Group } & \multirow[t]{2}{*}{ model } & \multicolumn{3}{|c|}{ Stay-at-home Order } & \multicolumn{3}{|c|}{ School Closure } \\
\hline & & Estimat & $\mathrm{SE}(95 \% \mathrm{CI})$ & $\mathrm{R}^{2}$ & Estimate & $\mathrm{SE}(95 \% \mathrm{CI})$ & $\mathrm{R}^{2}$ \\
\hline \multirow[t]{2}{*}{ Total Population } & Not Adjusted & $466.62 * * *$ & $102.86(265.01-668.23)$ & 0.78 & 117.18 & $90.37(-59.95-294.32)$ & 0.78 \\
\hline & TVA & $439.19 * * *$ & $94.88(253.22-625.17)$ & 0.82 & 82.93 & $83.03(-79.82-245.68)$ & 0.82 \\
\hline \multirow[t]{2}{*}{ Female } & Not Adjusted & $322.89 * * *$ & $55.02(215.06-430.73)$ & 0.79 & $113.61^{* *}$ & $48.35(18.85-208.38)$ & 0.79 \\
\hline & TVA & $292.37 * * *$ & $51.09(192.22-392.51)$ & 0.82 & $89.99 * *$ & $44.57(2.63-177.35)$ & 0.82 \\
\hline \multirow[t]{2}{*}{ Male } & Not Adjusted & $144.06 * * *$ & $48.1(49.78-238.34)$ & 0.78 & -11.9 & $42.25(-94.72-70.91)$ & 0.78 \\
\hline & TVA & $187.27 * * *$ & $44.83(99.4-275.14)$ & 0.82 & 18.36 & $39.1(-58.28-95.0)$ & 0.82 \\
\hline \multirow[t]{2}{*}{ Panic disorder } & Not Adjusted & $170.79 * * *$ & $23.48(124.76-216.81)$ & 0.8 & $71.45^{* * *}$ & $20.64(31.0-111.9)$ & 0.8 \\
\hline & TVA & $137.75 * * *$ & $21.71(95.2-180.3)$ & 0.83 & $47.78 * *$ & $18.94(10.65-84.91)$ & 0.83 \\
\hline \multirow[t]{2}{*}{ Reaction to sever stress } & Not Adjusted & $125.04 * * *$ & $18.98(87.85-162.24)$ & 0.77 & $36.31 * *$ & $16.68(3.62-69.0)$ & 0.77 \\
\hline & TVA & $110.54 * * *$ & $17.98(75.3-145.79)$ & 0.81 & 25.02 & $15.7(-5.75-55.78)$ & 0.81 \\
\hline \multirow{2}{*}{$\begin{array}{l}\text { Major depressive disorder, } \\
\text { recurrent }\end{array}$} & Not Adjusted & $88.15 * * *$ & $15.41(57.93-118.36)$ & 0.78 & $24.53 *$ & $13.54(-2.02-51.07)$ & 0.78 \\
\hline & TVA & $74.41 * * *$ & $14.13(46.71-102.12)$ & 0.82 & 15.01 & $12.33(-9.17-39.19)$ & 0.82 \\
\hline \multirow{2}{*}{$\begin{array}{l}\text { Major depressive disorder, } \\
\text { single episode }\end{array}$} & Not Adjusted & $35.63 * * *$ & $10.04(15.95-55.32)$ & 0.78 & 8.82 & $8.82(-8.46-26.11)$ & 0.78 \\
\hline & TVA & $36.61^{* * *}$ & $9.46(18.06-55.15)$ & 0.81 & 9.91 & $8.25(-6.27-26.09)$ & 0.81 \\
\hline \multirow[t]{2}{*}{ Attention-deficit hyperactivity } & Not Adjusted & $59.13 * * *$ & $12.48(34.67-83.59)$ & 0.74 & 15.16 & $10.94(-6.27-36.59)$ & 0.74 \\
\hline & TVA & $57.42 * * *$ & $11.53(34.82-80.01)$ & 0.79 & $16.87 *$ & $10.04(-2.81-36.55)$ & 0.79 \\
\hline \multirow[t]{2}{*}{ Insomnia } & Not Adjusted & $5.83 * * *$ & $1.27(3.34-8.33)$ & 0.76 & $2.32 * *$ & $1.09(0.18-4.47)$ & 0.76 \\
\hline & TVA & 0.17 & $1.17(-2.12-2.46)$ & 0.81 & -1.51 & $1.0(-3.47-0.44)$ & 0.81 \\
\hline \multirow[t]{2}{*}{ Life management difficulty } & Not Adjusted & $6.51 * *$ & $2.55(1.51-11.51)$ & 0.42 & $-14.35 * * *$ & $1.96(-18.19-10.51)$ & 0.43 \\
\hline & TVA & $6.69 * *$ & $2.58(1.62-11.76)$ & 0.44 & $-14.88 * * *$ & $1.99(-18.78-10.98)$ & 0.44 \\
\hline \multirow[t]{2}{*}{$1-10$ yrs } & Not Adjusted & $29.48^{* *}$ & $14.12(1.79-57.16)$ & 0.72 & 9 & $12.37(-15.24-33.25)$ & 0.72 \\
\hline & TVA & $27.1 * *$ & $12.7(2.21-51.98)$ & 0.78 & 10.66 & $11.05(-11.0-32.32)$ & 0.78 \\
\hline \multirow[t]{2}{*}{$11-20$ yrs } & Not Ac & $82.17 * * *$ & $21.12(40.77-123.57)$ & 0.73 & 27.29 & $18.55(-9.06-63.65)$ & 0.73 \\
\hline & TVA & $83.2 * * *$ & $19.67(44.64-121.75)$ & 0.78 & $30.4 *$ & $17.16(-3.24-64.03)$ & 0.78 \\
\hline \multirow[t]{2}{*}{$21-30$ yrs } & Not Adjusted & $112.63 * * *$ & $15.57(82.11-143.14)$ & 0.79 & $28.11 * *$ & $13.68(1.29-54.92)$ & 0.79 \\
\hline & TVA & $101.35 * * *$ & $14.81(72.31-130.38)$ & 0.82 & 19.2 & $12.93(-6.14-44.54)$ & 0.82 \\
\hline \multirow[t]{2}{*}{$31-40$ yrs } & Not Adjusted & $119.83^{* * *}$ & $17.96(84.63-155.03)$ & 0.78 & $32.85 * *$ & $15.78(1.92-63.79)$ & 0.78 \\
\hline & TVA & $112.31^{* * *}$ & $17.25(78.51-146.12)$ & 0.81 & $26.83 *$ & $15.05(-2.68-56.33)$ & 0.81 \\
\hline \multirow[t]{2}{*}{$41-50$ yrs } & Not Adjusted & $71.05 * * *$ & $13.31(44.97-97.14)$ & 0.79 & $24.35 * *$ & $11.68(1.45-47.25)$ & 0.79 \\
\hline & TVA & $68.33 * * *$ & $12.66(43.52-93.14)$ & 0.82 & $22.11 * *$ & $11.04(0.47-43.74)$ & 0.82 \\
\hline \multirow[t]{2}{*}{$51-60$ yrs } & Not Adjusted & $52.12 * * *$ & $14.51(23.68-80.55)$ & 0.78 & 9.86 & $12.73(-15.09-34.8)$ & 0.78 \\
\hline & TVA & $55.73 * * *$ & $13.67(28.94-82.52)$ & 0.81 & 11.92 & $11.91(-11.42-35.27)$ & 0.81 \\
\hline \multirow[t]{2}{*}{$61-70$ yrs } & Not Adjusted & $16.76 * *$ & $8.51(0.07-33.44)$ & 0.79 & -1.44 & $7.46(-16.06-13.18)$ & 0.79 \\
\hline & TVA & 22.22 *** & $7.88(6.78-37.66)$ & 0.83 & 1.89 & $6.86(-11.55-15.34)$ & 0.83 \\
\hline \multirow[t]{2}{*}{$71-80$ yrs } & Not Adjusted & -2.49 & $3.55(-9.45-4.46)$ & 0.79 & -2.62 & $3.1(-8.69-3.45)$ & 0.79 \\
\hline & TVA & -1.16 & $3.18(-7.4-5.07)$ & 0.84 & -1.55 & $2.76(-6.96-3.85)$ & 0.84 \\
\hline \multirow[t]{2}{*}{$81-90$ yrs } & Not Adjusted & $-7.45 * * *$ & $1.95(-11.27-3.62)$ & 0.75 & $-6.46 * * *$ & $1.69(-9.78-3.14)$ & 0.75 \\
\hline & TVA & $-3.97 * *$ & $1.8(-7.49-0.44)$ & 0.8 & $-3.54 * *$ & $1.55(-6.58-0.49)$ & 0.8 \\
\hline
\end{tabular}

Notes: Each row represents two coefficients of two DID regression models, stay-at-home order and school closure regression models with raw total population in states, with state and date as fixed effects using Eq. 2 We controlled for COVID-19 confirmed cases to adjust the models using Eq. 4 for the TVA model

$* * * p<0.01$

$* * p<0.05$

$* p<0.1$ 
Table B.6: Effects on mental health in counties $z$-months after lockdown

\begin{tabular}{|c|c|c|c|c|c|c|c|}
\hline \multirow[t]{2}{*}{ Group } & \multirow[t]{2}{*}{ Period } & \multicolumn{3}{|c|}{ Stay-at-home Order } & \multicolumn{3}{|c|}{ School Closure } \\
\hline & & Estimat & SE $(95 \% \mathrm{CI})$ & $\mathrm{R}^{2}$ & Estimate & SE $(95 \% \mathrm{CI})$ & $\mathrm{R}^{2}$ \\
\hline \multirow{3}{*}{ Total Population } & 1-month & $5.4534 * * *$ & $0.65(1.39-3.923)$ & 2.729 & 1.63 & $1.1(-0.53-3.79)$ & 0.73 \\
\hline & 5-month & $8.1074 * * *$ & $1.41(1.203-6.741)$ & 5.75 & $2.22 * *$ & $0.81(0.64-3.8)$ & 0.73 \\
\hline & 9-month & $9.79^{* * *}$ & $0.84(8.15-11.43)$ & 0.73 & $2.35 * * *$ & $0.74(0.89-3.81)$ & 0.73 \\
\hline \multirow{3}{*}{ Female } & 1-month & 3.95 *** & $0.62(2.73-5.17)$ & 0.74 & $1.38^{* *}$ & $0.61(0.18-2.57)$ & 0.73 \\
\hline & 5-month & $6.08 * * *$ & $0.49(5.12-7.05)$ & 0.74 & $2.03 * * *$ & $0.45(1.14-2.92)$ & 0.73 \\
\hline & 9-month & $7.32 * * *$ & $0.48(6.38-8.26)$ & 0.73 & $2.21 * * *$ & $0.42(1.38-3.03)$ & 0.73 \\
\hline \multirow[t]{3}{*}{ Male } & 1-month & $2.25 * * *$ & $0.61(1.05-3.44)$ & 0.73 & $4.46 * * *$ & $0.56(3.37-5.55)$ & 0.73 \\
\hline & 5-month & 3.05 *** & $0.47(2.13-3.96)$ & 0.73 & $3.81 * * *$ & $0.47(2.89-4.73)$ & 0.73 \\
\hline & 9-month & $3.68^{* * *}$ & $0.44(2.81-4.55)$ & 0.73 & 0.04 & $0.39(-0.72-0.81)$ & 0.73 \\
\hline \multirow[t]{3}{*}{ Panic disorder } & 1-month & $1.71^{* * *}$ & $0.29(1.13-2.28)$ & 0.75 & $0.64 * *$ & $0.29(0.08-1.2)$ & 0.74 \\
\hline & 5-month & 3.34 *** & $0.24(2.87-3.8)$ & 0.75 & $1.12 * * *$ & $0.21(0.7-1.54)$ & 0.74 \\
\hline & 9-month & $4.06 * * *$ & $0.23(3.6-4.52)$ & 0.74 & $1.25 * * *$ & $0.2(0.84-1.65)$ & 0.74 \\
\hline \multirow[t]{3}{*}{ Reaction to sever stress } & 1-month & 2.26 *** & $0.3(1.68-2.84)$ & 0.71 & 0.3 & $0.31(-0.3-0.91)$ & 0.69 \\
\hline & 5-month & 2.93 *** & $0.23(2.47-3.39)$ & 0.7 & $0.69 * * *$ & $0.22(0.26-1.12)$ & 0.7 \\
\hline & 9-month & $3.38^{* * *}$ & $0.23(2.93-3.83)$ & 0.7 & $0.65 * * *$ & $0.2(0.26-1.05)$ & 0.7 \\
\hline \multirow{3}{*}{$\begin{array}{l}\text { Major depressive disorder, } \\
\text { recurrent }\end{array}$} & 1-month & $0.85 * * *$ & $0.24(0.37-1.32)$ & 0.72 & -0.05 & $0.23(-0.5-0.39)$ & 0.71 \\
\hline & 5-month & $1.81 * * *$ & $0.19(1.43-2.18)$ & 0.72 & $0.35 * *$ & $0.17(0.01-0.69)$ & 0.71 \\
\hline & 9-month & $2.27 * * *$ & $0.19(1.91-2.63)$ & 0.71 & $0.36 * *$ & $0.16(0.04-0.68)$ & 0.71 \\
\hline \multirow{3}{*}{$\begin{array}{l}\text { Major depressive disorder, } \\
\text { single episode }\end{array}$} & 1-month & 0.13 & $0.17(-0.2-0.47)$ & 0.72 & -0.21 & $0.16(-0.52-0.1)$ & 0.71 \\
\hline & 5-month & $0.69^{* * *}$ & $0.13(0.43-0.95)$ & 0.71 & 0.03 & $0.12(-0.2-0.26)$ & 0.71 \\
\hline & 9-month & 0.96 *** & $0.13(0.71-1.21)$ & 0.71 & 0.09 & $0.11(-0.12-0.31)$ & 0.71 \\
\hline \multirow[t]{3}{*}{ Attention-deficit hyperactivity } & 1-month & $1.43^{* * *}$ & $0.23(0.97-1.89)$ & 0.62 & 0.25 & $0.22(-0.18-0.67)$ & 0.62 \\
\hline & 5-month & $1.56^{* * *}$ & $0.18(1.21-1.91)$ & 0.62 & $0.3 *$ & $0.16(-0.01-0.61)$ & 0.62 \\
\hline & 9-month & $1.78^{* * *}$ & $0.17(1.45-2.11)$ & 0.62 & $0.36 * *$ & $0.14(0.08-0.64)$ & 0.62 \\
\hline \multirow[t]{3}{*}{ Insomnia } & 1-month & $0.2 * * *$ & $0.06(0.08-0.32)$ & 0.58 & 0.05 & $0.05(-0.05-0.16)$ & 0.56 \\
\hline & 5-month & $0.22 * * *$ & $0.05(0.12-0.31)$ & 0.57 & 0.06 & $0.04(-0.02-0.14)$ & 0.57 \\
\hline & 9-month & $0.27 * * *$ & $0.05(0.17-0.35)$ & 0.57 & 0.03 & $0.04(-0.05-0.1)$ & 0.57 \\
\hline \multirow[t]{3}{*}{ Life management difficulty } & 1-month & -0.34 & $0.77(-1.84-1.17)$ & 0.3 & $-1.98 * *$ & $0.96(-3.87-0.1)$ & 0.32 \\
\hline & 5-month & 0.88 & $0.7(-0.49-2.24)$ & 0.32 & $-3.66 * * *$ & $0.6(-4.83-2.48)$ & 0.31 \\
\hline & 9-month & $1.34 *$ & $0.78(-0.18-2.86)$ & 0.3 & $-5.14 * * *$ & $0.5(-6.12-4.17)$ & 0.3 \\
\hline \multirow[t]{3}{*}{$1-10 \mathrm{yrs}$} & 1-month & 0.25 & $0.29(-0.32-0.82)$ & 0.61 & $-0.45 *$ & $0.27(-0.97-0.07)$ & 0.61 \\
\hline & 5-month & $0.69^{* * *}$ & $0.22(0.27-1.12)$ & 0.61 & -0.19 & $0.19(-0.56-0.19)$ & 0.61 \\
\hline & 9-month & $1.09 * * *$ & $0.2(0.69-1.49)$ & 0.61 & 0.17 & $0.18(-0.17-0.51)$ & 0.61 \\
\hline \multirow[t]{3}{*}{$11-20 \mathrm{yrs}$} & 1-month & $1.54^{* * *}$ & $0.34(0.87-2.22)$ & 0.62 & 0.3 & $0.33(-0.35-0.95)$ & 0.62 \\
\hline & 5-month & $1.68^{* * *}$ & $0.26(1.16-2.19)$ & 0.62 & 0.4 & $0.24(-0.08-0.87)$ & 0.62 \\
\hline & 9-month & $2.08 * * *$ & $0.25(1.59-2.57)$ & 0.62 & $0.6 * * *$ & $0.22(0.17-1.02)$ & 0.62 \\
\hline $21-30 \mathrm{yrs}$ & 1-month & $1.8 * * *$ & $0.24(1.32-2.27)$ & 0.76 & 0.37 & $0.25(-0.11-0.86)$ & 0.75 \\
\hline & 5-month & $2.75 * * *$ & $0.2(2.37-3.14)$ & 0.76 & $0.65 * * *$ & $0.18(0.3-1.0)$ & 0.75 \\
\hline & 9-month & 3.39 *** & $0.19(3.02-3.77)$ & 0.75 & $0.78 * * *$ & $0.17(0.46-1.11)$ & 0.75 \\
\hline $31-40 \mathrm{yrs}$ & 1-month & $2.55 * * *$ & $0.27(2.02-3.08)$ & 0.75 & $0.76^{* * *}$ & $0.27(0.23-1.29)$ & 0.75 \\
\hline & 5-month & 3.11 *** & $0.21(2.69-3.53)$ & 0.75 & $0.9 * * *$ & $0.19(0.52-1.28)$ & 0.75 \\
\hline & 9-month & 3.52 *** & $0.21(3.12-3.92)$ & 0.75 & $0.88 * * *$ & $0.18(0.53-1.23)$ & 0.75 \\
\hline $41-50 \mathrm{yrs}$ & 1-month & $1.62 * * *$ & $0.21(1.2-2.04)$ & 0.74 & 0.69 *** & $0.21(0.28-1.09)$ & 0.74 \\
\hline & 5-month & $2.02 * * *$ & $0.17(1.7-2.35)$ & 0.74 & $0.82 * * *$ & $0.15(0.52-1.11)$ & 0.74 \\
\hline & 9-month & $2.21 * * *$ & $0.16(1.9-2.52)$ & 0.74 & $0.72 * * *$ & $0.14(0.45-0.99)$ & 0.74 \\
\hline $51-60 \mathrm{yrs}$ & 1-month & $0.85 * * *$ & $0.26(0.34-1.36)$ & 0.72 & 0.03 & $0.24(-0.43-0.5)$ & 0.72 \\
\hline & 5-month & $1.4^{* * * *}$ & $0.2(1.01-1.79)$ & 0.73 & $0.3 *$ & $0.18(-0.04-0.65)$ & 0.73 \\
\hline & 9-month & $1.62 * * *$ & $0.19(1.25-1.99)$ & 0.73 & 0.2 & $0.16(-0.11-0.52)$ & 0.73 \\
\hline $61-70 \mathrm{yrs}$ & 1-month & -0.08 & $0.18(-0.44-0.27)$ & 0.73 & -0.1 & $0.16(-0.41-0.21)$ & 0.73 \\
\hline & 5-month & $0.41 * * *$ & $0.14(0.14-0.68)$ & 0.73 & 0 & $0.12(-0.23-0.23)$ & 0.73 \\
\hline & 9-month & $0.57 * * *$ & $0.13(0.32-0.82)$ & 0.73 & -0.11 & $0.11(-0.32-0.1)$ & 0.73 \\
\hline $71-80 \mathrm{yrs}$ & 1-month & $-0.27 * *$ & $0.1(-0.46-0.08)$ & 0.73 & -0.05 & $0.08(-0.2-0.11)$ & 0.73 \\
\hline & 5-month & -0.01 & $0.07(-0.15-0.13)$ & 0.73 & -0.04 & $0.06(-0.15-0.08)$ & 0.73 \\
\hline & 9 -month & 0.04 & $0.07(-0.09-0.17)$ & 0.73 & -0.07 & $0.05(-0.17-0.04)$ & 0.73 \\
\hline $81-90 \mathrm{yrs}$ & 1-month & $-0.14 * * *$ & $-0.04(-0.06-0.21)$ & 0.68 & $-0.24 * * *$ & $0.06(-0.36-0.12)$ & 0.68 \\
\hline & 5-month & $-0.13 * * *$ & $-0.03(-0.07-0.19)$ & 0.68 & $-0.23 * * *$ & $0.04(-0.32-0.15)$ & 0.68 \\
\hline & 9-month & $-0.24 * * *$ & $0.05(-0.34-0.14)$ & 0.68 & $-0.25 * * *$ & $0.04(-0.33-0.17)$ & 0.68 \\
\hline
\end{tabular}

Notes: Each row represents two coefficients of two DID regression models, stay-at-home order and school closure regression models with raw total population in counties, with county and date as fixed effects using Eq. 1 Each mental health group has been evaluated on 3 different points of time $z$ with regard to $z=\{1,5,9\}$-months after lockdown, to observe the dynamic effect of lockdown.

$* * * p<0.01$

$* * p<0.05$

$* p<0.1$ 
Table B.7: Effects on mental health in states $z$-months after lockdown

\begin{tabular}{|c|c|c|c|c|c|c|c|}
\hline \multirow[t]{2}{*}{ Group } & \multirow[t]{2}{*}{ Period } & \multicolumn{3}{|c|}{ Stay-at-home Order } & \multicolumn{3}{|c|}{ School Closure } \\
\hline & & Estimat & SE $(95 \% \mathrm{CI})$ & $\mathrm{R}^{2}$ & Estimate & SE $(95 \%$ CI $)$ & $\mathrm{R}^{2}$ \\
\hline \multirow[t]{3}{*}{ Total Population } & 1-month & $274.81 *$ & $139.95(0.51-549.11)$ & 0.78 & 35.86 & $126.85(-212.76-284.48)$ & 0.78 \\
\hline & 5-month & $384.0 * * *$ & $108.19(171.95-596.05)$ & 0.78 & 96.43 & $96.23(-92.17-285.04)$ & 0.78 \\
\hline & 9-month & $466.62 * * *$ & $102.86(265.01-668.23)$ & 0.78 & 117.18 & $90.38(-59.95-294.32)$ & 0.78 \\
\hline \multirow[t]{3}{*}{ Female } & 1-month & $181.37 * *$ & $72.74(38.79-323.95)$ & 0.79 & 48.47 & $65.99(-80.87-177.81)$ & 0.78 \\
\hline & 5-month & $266.64 * * *$ & $57.24(154.44-378.83)$ & 0.79 & $97.35 *$ & $50.92(-2.45-197.14)$ & 0.78 \\
\hline & 9 -month & $322.89 * * *$ & $55.02(215.06-430.73)$ & 0.79 & $113.61 * *$ & $48.35(18.85-208.38)$ & 0.79 \\
\hline \multirow[t]{3}{*}{ Male } & 1-month & 93.85 & $67.37(-38.19-225.89)$ & 0.78 & -26.18 & $60.88(-145.5-93.14)$ & 0.77 \\
\hline & 5-month & $117.9^{* *}$ & $51.19(17.57-218.23)$ & 0.78 & -16.06 & $45.49(-105.22-73.09)$ & 0.77 \\
\hline & 9-month & $144.06 * * *$ & $48.1(49.78-238.34)$ & 0.78 & -11.9 & $42.25(-94.72-70.91)$ & 0.78 \\
\hline \multirow[t]{3}{*}{ Panic disorder } & 1-month & $79.53 * *$ & $29.55(21.61-137.45)$ & 0.8 & 30.78 & $27.17(-22.47-84.03)$ & 0.8 \\
\hline & 5-month & $140.9 * * *$ & $24.04(93.78-188.02)$ & 0.8 & $62.69 * * *$ & $21.44(20.66-104.72)$ & 0.8 \\
\hline & 9 -month & $170.79 * * *$ & $23.48(124.76-216.81)$ & 0.8 & $71.45 * * *$ & $20.64(31.0-111.9)$ & 0.79 \\
\hline \multirow[t]{3}{*}{ Reaction to sever stress } & 1-month & $86.29 * * *$ & $24.49(38.28-134.3)$ & 0.78 & 16.74 & $23.18(-28.7-62.18)$ & 0.76 \\
\hline & 5-month & 107.24 *** & $19.45(69.12-145.35)$ & 0.77 & $34.65 *$ & $17.57(0.2-69.09)$ & 0.77 \\
\hline & 9-month & $125.04 * * *$ & $18.98(87.85-162.24)$ & 0.77 & $36.31 * *$ & $16.68(3.62-68.99)$ & 0.77 \\
\hline \multirow{3}{*}{$\begin{array}{l}\text { Major depressive disorder, } \\
\text { recurrent }\end{array}$} & 1-month & $38.17 *$ & $20.02(-1.08-77.41)$ & 0.78 & 1.84 & $18.05(-33.54-37.22)$ & 0.78 \\
\hline & onth & $70.4^{* * *}$ & 15.98 & 0.78 & 21.61 & $14.18(-6$. & 0.78 \\
\hline & 9-month & $88.15 * * *$ & $15.42(57.93-118.36)$ & 0.78 & $24.53 *$ & $13.54(-2.02-51.07)$ & 0.78 \\
\hline \multirow{3}{*}{$\begin{array}{l}\text { Major depressive disorder, } \\
\text { single episode }\end{array}$} & 1-month & 8.59 & $13.37(-17.62-34.79)$ & 0.78 & -4.7 & $12.14(-28.5-19.1)$ & 0.78 \\
\hline & 5-month & $26.49 * *$ & 10.47 & 0.78 & 5.28 & $9.31(-12.98$ & 0.78 \\
\hline & 9-month & 35.63 *** & $10.04(15.95-$ & 0.78 & 8.82 & $8.82(-8.46-26.1)$ & 0.78 \\
\hline \multirow[t]{3}{*}{ Attention-deficit hyperactivity } & 1-month & $49.23 * *$ & $17.55(14.83-83.63)$ & 0.74 & 10.04 & $15.75(-20.83-40.9)$ & 0.74 \\
\hline & 5-month & $51.22 * * *$ & $13.27(25.2-77.23)$ & 0.74 & 11.71 & $11.77(-11.36-34.78)$ & 0.74 \\
\hline & 9-month & $59.13 * * *$ & $12.48(34.67-83.59)$ & 0.74 & 15.16 & $10.93(-6.27-36.59)$ & 0.74 \\
\hline \multirow[t]{3}{*}{ Insomnia } & 1-month & 3.62 ** & $1.64(0.42-6.83)$ & 0.76 & 1.96 & $1.46(-0.9-4.82)$ & 0.75 \\
\hline & 5-month & $5.03 * * *$ & $1.33(2.42-7.65)$ & 0.76 & $2.89 * *$ & $1.16(0.61-5.17)$ & 0.75 \\
\hline & 9-month & $5.83 * * *$ & $1.27(3.34-8.33)$ & 0.76 & $2.32 * *$ & $1.09(0.18-4.47)$ & 0.76 \\
\hline \multirow[t]{3}{*}{ Life management difficulty } & 1-month & 0.2 & $2.51(-4.71-5.11)$ & 0.45 & -4.38 & $3.51(-11.26-2.49)$ & 0.48 \\
\hline & 5-month & $4.51 *$ & $2.4(-0.19-9.2)$ & 0.44 & $-9.5 * * *$ & $2.3(-14.01-4.98)$ & 0.46 \\
\hline & 9 -month & $6.51 * *$ & $2.55(1.51-11.51)$ & 0.43 & $-14.35 * * *$ & $1.96(-18.19-10.51)$ & 0.43 \\
\hline \multirow[t]{3}{*}{$1-10 \mathrm{yrs}$} & 1-month & 3.05 & $19.82(-35.79-41.89)$ & 0.71 & -16.58 & $17.64(-51.15-17.98)$ & 0.71 \\
\hline & 5-month & 16.32 & $14.84(-12.77-45.42)$ & 0.71 & -4.53 & $13.09(-30.18-21.12)$ & 0.71 \\
\hline & 9 -month & $29.48 * *$ & $14.12(1.79-57.16)$ & 0.72 & 9 & $12.37(-15.24-33.25)$ & 0.72 \\
\hline \multirow[t]{3}{*}{$11-20 \mathrm{yrs}$} & 1-month & $67.83^{* *}$ & $29.37(10.26-125.4)$ & 0.74 & 11.1 & $26.53(-40.9-63.11)$ & 0.73 \\
\hline & 5-month & 67.56 *** & $22.32(23.81-111.32)$ & 0.73 & 16.59 & $19.87(-22.36-55.54)$ & 0.73 \\
\hline & 9-month & $82.17 * * *$ & $21.12(40.77-123.57)$ & 0.73 & 27.29 & $18.55(-9.06-63.65)$ & 0.73 \\
\hline $21-30 \mathrm{yrs}$ & 1-month & $63.26 * * *$ & $19.86(24.33-102.19)$ & 0.8 & 10.85 & $18.46(-25.33-47.02)$ & 0.79 \\
\hline & 5-month & $90.9^{* * *}$ & $15.97(59.6-122.19)$ & 0.79 & 23.01 & $14.3(-5.02-51.03)$ & 0.79 \\
\hline & 9 -month & $112.63 * * *$ & $15.57(82.11-143.14)$ & 0.79 & $28.11 * *$ & $13.68(1.29-54.92)$ & 0.79 \\
\hline $31-40$ yrs & 1-month & 89.59 *** & $24.18(42.19-136.99)$ & 0.78 & 26.6 & $22.09(-16.7-69.91)$ & 0.78 \\
\hline & 5 -month & $105.21 * * *$ & $18.86(68.24-142.17)$ & 0.78 & $32.31 *$ & $16.81(-0.64-65.25)$ & 0.78 \\
\hline & 9-month & $119.83^{* * *}$ & $17.96(84.63-155.03)$ & 0.78 & $32.85^{* *}$ & $15.78(1.92-63.79)$ & 0.78 \\
\hline $41-50$ yrs & 1-month & $52.44 * * *$ & $18.13(16.9-87.98)$ & 0.79 & 22.19 & $16.44(-10.02-54.41)$ & 0.78 \\
\hline & 5-month & $63.72 * * *$ & $14.08(36.12-91.32)$ & 0.78 & $27.21 * *$ & $12.52(2.67-51.74)$ & 0.78 \\
\hline & 9-month & $71.05 * * *$ & $13.31(44.97-97.13)$ & 0.79 & $24.35 * *$ & $11.68(1.45-47.25)$ & 0.79 \\
\hline $51-60 \mathrm{yrs}$ & 1-month & 28.05 & $20.03(-11.22-67.31)$ & 0.78 & 3.68 & $17.93(-31.47-38.83)$ & 0.77 \\
\hline & 5-month & $45.37 * * *$ & $15.47(15.04-75.7)$ & 0.78 & 13 & $13.69(-13.83-39.82)$ & 0.77 \\
\hline & 9-month & $52.12 * * *$ & $14.51(23.68-80.55)$ & 0.78 & 9.86 & $12.73(-15.09-34.8)$ & 0.78 \\
\hline $61-70 \mathrm{yrs}$ & 1-month & -3.42 & $11.83(-26.6-19.76)$ & 0.79 & -5.24 & $10.58(-25.98-15.51)$ & 0.78 \\
\hline & 5-month & 12.32 & $9.11(-5.53-30.17)$ & 0.79 & 1.44 & $8.05(-14.33-17.21)$ & 0.78 \\
\hline & 9 -month & $16.76^{*}$ & $8.51(0.07-33.44)$ & 0.79 & -1.44 & $7.46(-16.06-13.18)$ & 0.79 \\
\hline $71-80 \mathrm{yrs}$ & 1-month & $-11.02 * *$ & $5.02(-20.86-1.19)$ & 0.79 & -3.96 & $4.41(-12.59-4.68)$ & 0.79 \\
\hline & 5-month & -3.76 & $3.83(-11.26-3.74)$ & 0.79 & -1.88 & $3.34(-8.44-4.67)$ & 0.79 \\
\hline & 9-month & -2.49 & $3.55(-9.45-4.47)$ & 0.79 & -2.62 & $3.1(-8.69-3.45)$ & 0.79 \\
\hline $81-90 \mathrm{yrs}$ & 1-month & $-9.6 * * *$ & $2.92(-15.31-3.88)$ & 0.75 & $-6.67 * *$ & $2.53(-11.62-1.72)$ & 0.75 \\
\hline & 5 -month & $-7.74 * * *$ & $2.15(-11.94-3.53)$ & 0.75 & $-6.01 * * *$ & $1.87(-9.67-2.35)$ & 0.75 \\
\hline & 9-month & $-7.45 * * *$ & $1.95(-11.27-3.62)$ & 0.75 & $-6.46 * * *$ & $1.69(-9.78-3.14)$ & 0.75 \\
\hline
\end{tabular}

Notes: Each row represents two coefficients of two DID regression models, stay-at-home order and school closure regression models with raw total population in states, with state and date as fixed effects using Eq. 2 Each mental health group has been evaluated on 3 different points of time $z$ with regard to $z=\{1,5,9\}$-months after lockdown, to observe the dynamic effect of lockdown.

$* * * p<0.01$

$* * p<0.05$

$* p<0.1$ 
Table B.8: Effects of lockdown interventions on mental health of different population groups in counties weighted by county-level population size

\begin{tabular}{|c|c|c|c|c|c|c|c|}
\hline \multirow[t]{2}{*}{ Group } & \multirow[t]{2}{*}{ model } & \multicolumn{3}{|c|}{ Stay-at-home Order } & \multicolumn{3}{|l|}{ School Closure } \\
\hline & & Estimat & SE $(95 \% \mathrm{CI})$ & $R^{2}$ & Estimate & $\mathrm{SE}(95 \% \mathrm{CI})$ & $R^{2}$ \\
\hline \multirow[t]{2}{*}{ Total Population } & Not Adjusted & $0.0001^{* * *}$ & $3.17 \times 10^{-6}(0.0-0.0)$ & 0.47 & $8.681 \times 10^{-5} * * *$ & $2.84 \times 10^{-6}\left(8.13 \times 10^{-5}-9.24 \times 10^{-5}\right)$ & 0.47 \\
\hline & TVA & $0.0001 * * *$ & $3.18 \times 10^{-6}(0.0-0.0)$ & 0.47 & $8.578 \times 10^{-5} * * *$ & $2.84 \times 10^{-6}\left(8.02 \times 10^{-5}-9.13 \times 10^{-5}\right)$ & 0.47 \\
\hline \multirow[t]{2}{*}{ Female } & Not Adjusted & $6.76 \times 10^{-5} * * *$ & $1.88 \times 10^{-6}\left(8.02 \times 10^{-5}-9.13 \times 10^{-5}\right)$ & 0.46 & $-1.67 \times 10^{-6}$ & $1.42 \times 10^{-6}\left(-4.45 \times 10^{-6}-1.11 \times 10^{-6}\right)$ & 0.46 \\
\hline & TVA & $6.662 \times 10^{-5} * * *$ & $1.89 \times 10^{-6}\left(6.29 \times 10^{-5}-7.03 \times 10^{-5}\right)$ & 0.466 & $-3.89 \times 10^{-6} * * *$ & $1.41 \times 10^{-6}\left(-6.66 \times 10^{-6}-1.12 \times 10^{-6}\right)$ & 0.47 \\
\hline \multirow[t]{2}{*}{ Male } & Not Adjusted & $5.766 \times 10^{-5} * * *$ & $1.7 \times 10^{-6}\left(-6.66 \times 10^{-6}-1.12 \times 10^{-6}\right)$ & 0.45 & $4.48 \times 10^{-6} * * *$ & $1.26 \times 10^{-6}\left(2 \times 10^{-6}-6.96 \times 10^{-6}\right)$ & 0.45 \\
\hline & TVA & $5.711 \times 10^{-5} * * *$ & $1.7 \times 10^{-6}\left(5.38 \times 10^{-5}-6.04 \times 10^{-5}\right)$ & 0.456 & $3.4 \times 10^{-6} * * *$ & $1.23 \times 10^{-5}\left(-2.071 \times 10^{-5}-2.751 \times 10^{-5}\right)$ & 0.46 \\
\hline \multirow[t]{2}{*}{ Panic disorder } & Not Adjusted & $3.334 \times 10^{-5} * * *$ & $9.3 \times 10^{-7}\left(3.15 \times 10^{-5}-3.52 \times 10^{-5}\right)$ & 0.48 & $1.975 \times 10^{-5} * * *$ & $8.1 \times 10^{-7}\left(1.82 \times 10^{-5}-2.13 \times 10^{-5}\right)$ & 0.48 \\
\hline & TVA & $3.219 \times 10^{-5} * * *$ & $9.3 \times 10^{-7}\left(3.04 \times 10^{-5}-3.4 \times 10^{-5}\right)$ & 0.48 & $1.88 \times 10^{-5} * * *$ & $8.1 \times 10^{-7}\left(1.72 \times 10^{-5}-2.04 \times 10^{-5}\right)$ & 0.48 \\
\hline \multirow{2}{*}{ Reaction to sever stress } & Not Adjusted & $2.011 \times 10^{-5} * * *$ & $1.01 \times 10^{-6}\left(1.81 \times 10^{-5}-2.21 \times 10^{-5}\right)$ & 0.42 & $1.404 \times 10^{-5} * * *$ & $8.9 \times 10^{-7}\left(1.23 \times 10^{-5}-1.58 \times 10^{-5}\right)$ & 0.42 \\
\hline & TVA & $1.965 \times 10^{-5} * * *$ & $1.01 \times 10^{-6}\left(1.77 \times 10^{-5}-2.16 \times 10^{-5}\right)$ & 0.42 & $1.332 \times 10^{-5} * * *$ & $8.9 \times 10^{-7}\left(1.16 \times 10^{-5}-1.51 \times 10^{-5}\right)$ & 0.42 \\
\hline \multirow[t]{2}{*}{ Major depressive disorder, recurrent } & Not Adjusted & $1.664 \times 10^{-5} * * *$ & $8.7 \times 10^{-7}\left(1.49 \times 10^{-5}-1.83 \times 10^{-5}\right)^{\prime}$ & 0.39 & $7.92 \times 10^{-6} * * *$ & $7.6 \times 10^{-7}\left(6.44 \times 10^{-6}-9.4 \times 10^{-6}\right)$ & 0.39 \\
\hline & TVA & $1.614 \times 10^{-5} * * *$ & $8.7 \times 10^{-7}\left(1.44 \times 10^{-5}-1.78 \times 10^{-5}\right)$ & 0.39 & $7.57 \times 10^{-6} * * *$ & $7.6 \times 10^{-7}\left(6.09 \times 10^{-6}-9.05 \times 10^{-6}\right)$ & 0.39 \\
\hline \multirow{2}{*}{ Major depressive disorder, single episode } & Not Adjusted & $1.248 \times 10^{-5} * * *$ & $5.7 \times 10^{-7}\left(1.14 \times 10^{-5}-1.36 \times 10^{-5}\right)$ & 0.49 & $8.82 \times 10^{-6} * * *$ & $4.9 \times 10^{-7}\left(7.86 \times 10^{-6}-9.78 \times 10^{-6}\right)$ & 0.49 \\
\hline & & $1.208 \times 10^{-5} * * *$ & $5.7 \times 10^{-7}\left(1.1 \times 10^{-5}-1.32 \times 10^{-5}\right)$ & 0.49 & $8.54 \times 10^{-6} * * *$ & $4.9 \times 10^{-7}\left(7.57 \times 10^{-6}-9.5 \times 10^{-6}\right)$ & 0.49 \\
\hline \multirow[t]{2}{*}{ Attention-deficit hyperactivity } & Not $\mathrm{Ad}$ & $3.18 \times 10^{-5} * * *$ & $1.01 \times 10^{-6}\left(2.98 \times 10^{-5}-3.38 \times 10^{-5}\right)$ & 0.39 & $1.544 \times 10^{-5} * * *$ & $8.7 \times 10^{-7}\left(1.37 \times 10^{-5}-1.71 \times 10^{-5}\right)$ & 0.39 \\
\hline & TVA & $3.136 \times 10^{-5} * * *$ & $1.01 \times 10^{-6}\left(2.94 \times 10^{-5}-3.33 \times 10^{-5}\right)$ & 0.39 & $1.524 \times 10^{-5} * * *$ & $8.7 \times 10^{-7}\left(1.35 \times 10^{-5}-1.69 \times 10^{-5}\right)$ & 0.39 \\
\hline \multirow{2}{*}{ Insomnia } & Not Adjusted & $4 \times 10^{-7} *$ & $2.3 \times 10^{-7}\left(-4 \times 10^{-8}-8.5 \times 10^{-7}\right)$ & 0.75 & $-5.3 \times 10^{-7} * * *$ & $1.8 \times 10^{-7}\left(-8.9 \times 10^{-7}-1.7 \times 10^{-7}\right)$ & 0.75 \\
\hline & & $4 \times 10^{-7 *}$ & $2.3 \times 10^{-7}\left(-5 \times 10^{-8}-8.4 \times 10^{-7}\right)$ & 0.75 & $-5.4 \times 10^{-7 * * *}$ & $1.8 \times 10^{-7}\left(-9 \times 10^{-7}-1.8 \times 10^{-7}\right)$ & 0.75 \\
\hline \multirow[t]{2}{*}{ Life management difficulty } & Not Ac & $9.7 \times 10^{-7}$ & $1.59 \times 10^{-6}\left(-2.15 \times 10^{-6}-4.09 \times 10^{-6}\right)$ & 0.51 & $-7.34 \times 10^{-6} * * *$ & $1.02 \times 10^{-6}\left(-9.34 \times 10^{-6}-5.34 \times 10^{-6}\right)$ & 0.51 \\
\hline & TVA & $1.79 \times 10^{-6}$ & $1.59 \times 10^{-6}\left(-1.33 \times 10^{-6}-4.9 \times 10^{-6}\right)$ & 0.52 & $-6.61 \times 10^{-6} * * *$ & $1.03 \times 10^{-6}\left(-8.63 \times 10^{-6}-4.59 \times 10^{-6}\right)$ & 0.52 \\
\hline \multirow{2}{*}{$1-10 \mathrm{yrs}$} & Not $\mathrm{Ad}$ & $9.3 \times 10^{-6} * * *$ & $9.5 \times 10^{-7}\left(7.44 \times 10^{-6}-1.12 \times 10^{-5}\right)$ & 0.39 & $8.84 \times 10^{-6} * * *$ & $8.2 \times 10^{-7}\left(7.24 \times 10^{-6}-1.04 \times 10^{-5}\right)$ & 0.39 \\
\hline & & $9.43 \times 10^{-6} * * *$ & $9.5 \times 10^{-7}\left(7.57 \times 10^{-6}-1.13 \times 10^{-5}\right)$ & 0.39 & $-4.4 \times 10^{-7}$ & $7.3 \times 10^{-7}\left(-1.87 \times 10^{-6}-9.9 \times 10^{-7}\right)$ & 0.39 \\
\hline \multirow[t]{2}{*}{$11-20$ yrs } & Not Ac & $2.991 \times 10^{-5} * * *$ & $1.43 \times 10^{-6}\left(2.71 \times 10^{-5}-3.27 \times 10^{-5}\right)$ & 0.35 & $2.226 \times 10^{-5} * * *$ & $1.26 \times 10^{-6}\left(1.98 \times 10^{-5}-2.47 \times 10^{-5}\right)$ & 0.35 \\
\hline & TVA & $2.972 \times 10^{-5} * * *$ & $1.44 \times 10^{-6}\left(2.69 \times 10^{-5}-3.25 \times 10^{-5}\right)$ & 0.35 & $-1.36 \times 10^{-6}$ & $1.1 \times 10^{-6}\left(-3.51 \times 10^{-6}-7.9 \times 10^{-7}\right)$ & 0.35 \\
\hline \multirow[t]{2}{*}{$21-30 \mathrm{yrs}$} & Not Adjusted & $1.562 \times 10^{-5} * * *$ & $6.5 \times 10^{-7}\left(1.43 \times 10^{-5}-1.69 \times 10^{-5}\right)$ & 0.53 & $8.28 \times 10^{-6} * * *$ & $5.6 \times 10^{-7}\left(7.17 \times 10^{-6}-9.38 \times 10^{-6}\right)$ & 0.53 \\
\hline & & $1.505 \times 10^{-5} * * *$ & $6.5 \times 10^{-7}\left(1.38 \times 10^{-5}-1.63 \times 10^{-5}\right)$ & 0.53 & $1 \times 10^{-8}$ & $5 \times 10^{-7}\left(-9.7 \times 10^{-7}-9.8 \times 10^{-7}\right)$ & 0.53 \\
\hline \multirow[t]{2}{*}{$31-40$ yrs } & Not Ac & $3.226 \times 10^{-5} * * *$ & $8.3 \times 10^{-7}\left(3.06 \times 10^{-5}-3.39 \times 10^{-5}\right)$ & 0.56 & $1.929 \times 10^{-5} * * *$ & $7.3 \times 10^{-7}\left(1.79 \times 10^{-5}-2.07 \times 10^{-5}\right)$ & 0.56 \\
\hline & TVA & $3.197 \times 10^{-5} * * *$ & $8.4 \times 10^{-7}\left(3.03 \times 10^{-5}-3.36 \times 10^{-5}\right)$ & 0.56 & $1.9 \times 10^{-7}$ & $6.4 \times 10^{-7}\left(-1.07 \times 10^{-6}-1.44 \times 10^{-6}\right)$ & 0.56 \\
\hline \multirow{2}{*}{$41-50 \mathrm{yrs}$} & Not Adjusted & $2.477 \times 10^{-5} * * *$ & $6.8 \times 10^{-7}\left(2.34 \times 10^{-5}-2.61 \times 10^{-5}\right)$ & 0.56 & $1.709 \times 10^{-5} * * *$ & $5.9 \times 10^{-7}\left(1.59 \times 10^{-5}-1.82 \times 10^{-5}\right)$ & 0.55 \\
\hline & & $2.454 \times 10^{-5} * * *$ & $6.8 \times 10^{-7}\left(2.32 \times 10^{-5}-2.59 \times 10^{-5}\right)$ & 0.56 & $1.03 \times 10^{-6 *}$ & $5.3 \times 10^{-7}\left(-1 \times 10^{-8}-2.06 \times 10^{-6}\right)$ & 0.56 \\
\hline \multirow{2}{*}{$51-60$ yrs } & Not Adjusted & $1.492 \times 10^{-5} * * *$ & $6 \times 10^{-7}\left(1.38 \times 10^{-5}-1.61 \times 10^{-5}\right)$ & 0.48 & $8.39 \times 10^{-6 * * *}$ & $5.1 \times 10^{-7}\left(7.39 \times 10^{-6}-9.39 \times 10^{-6}\right)$ & 0.48 \\
\hline & TVA & $1.469 \times 10^{-5} * * *$ & $6 \times 10^{-7}\left(1.35 \times 10^{-5}-1.59 \times 10^{-5}\right)$ & 0.48 & $-5.3 \times 10^{-7}$ & $4.5 \times 10^{-7}\left(-1.43 \times 10^{-6}-3.6 \times 10^{-7}\right)$ & 0.48 \\
\hline \multirow[t]{2}{*}{$61-70 \mathrm{yrs}$} & Not Adjusted & $6.82 \times 10^{-6} * * *$ & $4.2 \times 10^{-7}\left(5.99 \times 10^{-6}-7.65 \times 10^{-6}\right)$ & 0.56 & $4.27 \times 10^{-6} * * *$ & $3.5 \times 10^{-7}\left(3.58 \times 10^{-6}-4.96 \times 10^{-6}\right)$ & 0.56 \\
\hline & TVA & $6.74 \times 10^{-6} * * *$ & $4.2 \times 10^{-7}\left(5.92 \times 10^{-6}-7.57 \times 10^{-6}\right)$ & 0.56 & $-4 \times 10^{-8}$ & $3.1 \times 10^{-7}\left(-6.6 \times 10^{-7}-5.7 \times 10^{-7}\right)$ & 0.56 \\
\hline \multirow{2}{*}{$71-80$ yrs } & Not Adjusted & $1.85 \times 10^{-6} * * *$ & $2.9 \times 10^{-7}\left(1.27 \times 10^{-6}-2.43 \times 10^{-6}\right)$ & 0.66 & $1.49 \times 10^{-6} * * *$ & $2.3 \times 10^{-7}\left(1.03 \times 10^{-6}-1.94 \times 10^{-6}\right)$ & 0.66 \\
\hline & TVA & $1.73 \times 10^{-6} * * *$ & $2.9 \times 10^{-7}\left(1.15 \times 10^{-6}-2.31 \times 10^{-6}\right)$ & 0.66 & $1.1 \times 10^{-7}$ & $2 \times 10^{-7}\left(-2.9 \times 10^{-7}-5.1 \times 10^{-7}\right)$ & 0.66 \\
\hline \multirow[t]{2}{*}{$81-90 \mathrm{yrs}$} & Not Adjusted & $1.79 \times 10^{-6} * * *$ & $3 \times 10^{-7}\left(1.21 \times 10^{-6}-2.37 \times 10^{-6}\right)$ & 0.74 & $9.7 \times 10^{-7} * * *$ & $2.3 \times 10^{-7}\left(5.2 \times 10^{-7}-1.42 \times 10^{-6}\right)$ & 0.74 \\
\hline & TVA & $1.68 \times 10^{-6} * * *$ & $3 \times 10^{-7}\left(1.1 \times 10^{-6}-2.27 \times 10^{-6}\right)$ & 0.75 & $1 \times 10^{-8}$ & $2 \times 10^{-7}\left(-3.8 \times 10^{-7}-4.1 \times 10^{-7}\right)$ & 0.75 \\
\hline
\end{tabular}

Notes: Each row represents two coefficients of two DID regression models, stay-at-home order and school closure regression models with normalized effects by population size in counties, with county and date as fixed effects using Eq. 1 We controlled for COVID-19 confirmed cases to adjust the models using Eq. 3 for the TVA model $* * * p<0.01$

$* * p<0.05$

$* p<0.1$ 
Table B.9: Effects of lockdown interventions on mental health of different population groups in states weighted by state-level population size

\begin{tabular}{|c|c|c|c|c|c|c|c|}
\hline \multirow[t]{2}{*}{ Group } & \multirow[t]{2}{*}{ model } & \multicolumn{3}{|c|}{ Stay-at-home Order } & \multicolumn{3}{|c|}{ School Closure } \\
\hline & & Estimat & $\mathrm{SE}(95 \% \mathrm{CI})$ & $R^{2}$ & Estimate & SE $(95 \%$ CI $)$ & $R^{2}$ \\
\hline \multirow[t]{2}{*}{ Total Population } & Not Adjusted & $8.8 \times 10^{-5} * * *$ & $1 \times 10^{-5}\left(6.9 \times 10^{-5}-0.0\right)$ & 0.8 & $1.3 \times 10^{-5}$ & $9 \times 10^{-6}\left(-4 \times 10^{-6}-3 \times 10^{-5}\right)$ & 0.8 \\
\hline & VAT & $8.6 \times 10^{-5} * * *$ & $1 \times 10^{-5}\left(6.6 \times 10^{-5}-0.0\right)$ & 0.8 & $1.3 \times 10^{-5}$ & $9 \times 10^{-6}\left(-4 \times 10^{-6}-2.9 \times 10^{-5}\right)$ & 0.8 \\
\hline Female & VAT & $5.2 \times 10^{-5} * * *$ & $5 \times 10^{-6}\left(4.1 \times 10^{-5}-6.3 \times 10^{-5}\right)$ & 0.81 & $5 \times 10^{-6}$ & $5 \times 10^{-6}\left(-4 \times 10^{-6}-1.4 \times 10^{-5}\right.$ & 0.81 \\
\hline \multirow[t]{2}{*}{ Male } & Not Adjusted & $3.8 \times 10^{-5} * * *$ & $5 \times 10^{-6}\left(2.9 \times 10^{-5}-4.7 \times 10^{-5}\right)$ & 0.79 & $6 \times 10^{-6}$ & $4 \times 10^{-6}\left(-2 \times 10^{-6}-1.3 \times 10^{-5}\right.$ & 0.79 \\
\hline & VAT & $4.1 \times 10^{-5} * * *$ & $5 \times 10^{-6}\left(3.2 \times 10^{-5}-5 \times 10^{-5}\right)$ & 0.79 & $5 \times 10^{-6}$ & $4 \times 10^{-6}\left(-2 \times 10^{-6}-1.3 \times 10^{-5}\right)$ & 0.79 \\
\hline Panic disorder & Not Adjusted & $2 \times 10^{-5} * * *$ & $3 \times 10^{-6}\left(1.5 \times 10^{-5}-2.5 \times 10^{-5}\right)$ & 0.8 & 0 & $2 \times 10^{-6}\left(-4 \times 10^{-6}-4 \times 10^{-6}\right)$ & 0.8 \\
\hline \multirow[t]{2}{*}{ Reaction to sever stress } & Not Adjusted & $1.3 \times 10^{-5} * * *$ & $2 \times 10^{-6}\left(8 \times 10^{-6}-1.7 \times 10^{-5}\right)$ & 0.78 & $-1 \times 10^{-6}$ & $2 \times 10^{-6}\left(-5 \times 10^{-6}-3 \times 10^{-6}\right)$ & 0.77 \\
\hline & VAT & $1.3 \times 10^{-5} * * *$ & $2 \times 10^{-6}\left(9 \times 10^{-6}-1.8 \times 10^{-5}\right)$ & 0.78 & $-1 \times 10^{-6}$ & $2 \times 10^{-6}\left(-5 \times 10^{-6}-3 \times 10^{-6}\right)$ & 0.78 \\
\hline \multirow{2}{*}{ Major depressive disorder, recurrent } & Not Adjusted & $1.3 \times 10^{-5} * * *$ & $2 \times 10^{-6}\left(1 \times 10^{-5}-1.6 \times 10^{-5}\right)$ & 0.77 & $-4 \times 10^{-6 * * *}$ & $1 \times 10^{-6}\left(-6 \times 10^{-6}-1 \times 10^{-6}\right)$ & 0.77 \\
\hline & VAT & $1.4 \times 10^{-5} * * *$ & $2 \times 10^{-6}\left(1 \times 10^{-5}-1.7 \times 10^{-5}\right)$ & 0.78 & $-3 \times 10^{-6 * *}$ & $1 \times 10^{-6}\left(-6 \times 10^{-6}-1 \times 10^{-6}\right)$ & 0.78 \\
\hline \multirow{2}{*}{ Major depressive disorder, single episode } & Not Adjusted & $7 \times 10^{-6} * * *$ & $1 \times 10^{-6}\left(5 \times 10^{-6}-9 \times 10^{-6}\right)$ & 0.78 & $2 \times 10^{-6 * *}$ & $1 \times 10^{-6}\left(0.0-4 \times 10^{-6}\right)$ & 0.77 \\
\hline & VAT & $7 \times 10^{-6 * * *}$ & $1 \times 10^{-6}\left(5 \times 10^{-6}-9 \times 10^{-6}\right)$ & 0.78 & $2 \times 10^{-6 * * *}$ & $1 \times 10^{-6}\left(1 \times 10^{-6}-4 \times 10^{-6}\right)$ & 0.78 \\
\hline \multirow{2}{*}{ Attention-deficit hyperactivity } & Not Adjusted & $1.4 \times 10^{-5} * * *$ & $1 \times 10^{-6}\left(1.1 \times 10^{-5}-1.7 \times 10^{-5}\right)$ & 0.7 & $5 \times 10^{-6 * * *}$ & $1 \times 10^{-6}\left(2 \times 10^{-6}-7 \times 10^{-6}\right)$ & 0.7 \\
\hline & VAT & $1.5 \times 10^{-5} * * *$ & $1 \times 10^{-6}\left(1.2 \times 10^{-5}-1.7 \times 10^{-5}\right)$ & 0.71 & $5 \times 10^{-6 * * *}$ & $1 \times 10^{-6}\left(2 \times 10^{-6}-7 \times 10^{-6}\right)$ & 0.71 \\
\hline Insomnia & Not Adjusted & 0 & $0.0\left(-0.0-1 \times 10^{-6}\right)$ & 0.63 & $-0.0 * * *$ & $0.0\left(-1 \times 10^{-6}-0.0\right)$ & 0.63 \\
\hline Life management difficulty & VAT & $1 \times 10^{-6} * * *$ & $0.0\left(0.0-2 \times 10^{-6}\right)$ & 0.44 & $-2 \times 10^{-6} * * *$ & $0.0\left(-3 \times 10^{-6}-2 \times 10^{-6}\right)$ & 0.45 \\
\hline \multirow[t]{2}{*}{$1-10 \mathrm{yrs}$} & Not Adjusted & $6 \times 10^{-6} * * *$ & $1 \times 10^{-6}\left(3 \times 10^{-6}-9 \times 10^{-6}\right)$ & 0.68 & $4 \times 10^{-6} * * *$ & $1 \times 10^{-6}\left(2 \times 10^{-6}-6 \times 10^{-6}\right)$ & 0.68 \\
\hline & VAT & $7 \times 10^{-6 * * *}$ & $1 \times 10^{-6}\left(4 \times 10^{-6}-1 \times 10^{-5}\right)$ & 0.69 & $4 \times 10^{-6} * * *$ & $1 \times 10^{-6}\left(2 \times 10^{-6}-7 \times 10^{-6}\right)$ & 0.69 \\
\hline \multirow[t]{2}{*}{$11-20$ yrs } & Not Adjusted & $1.5 \times 10^{-5} * * *$ & $2 \times 10^{-6}\left(1 \times 10^{-5}-2 \times 10^{-5}\right)$ & 0.7 & $8 \times 10^{-6} * * *$ & $2 \times 10^{-6}\left(4 \times 10^{-6}-1.2 \times 10^{-5}\right)$ & 0.7 \\
\hline & VAT & $1.7 \times 10^{-5} * * *$ & $2 \times 10^{-6}\left(1.2 \times 10^{-5}-2.1 \times 10^{-5}\right)$ & 0.7 & $8 \times 10^{-6} * * *$ & $2 \times 10^{-6}\left(4 \times 10^{-6}-1.2 \times 10^{-5}\right)$ & 0.7 \\
\hline \multirow[t]{2}{*}{$21-30 \mathrm{yrs}$} & Not Adjusted & $1.6 \times 10^{-5} * * *$ & $2 \times 10^{-6}\left(1.3 \times 10^{-5}-1.9 \times 10^{-5}\right)$ & 0.8 & $-4 \times 10^{-6} * * *$ & $1 \times 10^{-6}\left(-7 \times 10^{-6}-2 \times 10^{-6}\right)$ & 0.8 \\
\hline & VAT & $1.6 \times 10^{-5} * * *$ & $2 \times 10^{-6}\left(1.3 \times 10^{-5}-2 \times 10^{-5}\right)$ & 0.81 & $-4 \times 10^{-6} * * *$ & $1 \times 10^{-6}\left(-7 \times 10^{-6}-2 \times 10^{-6}\right)$ & 0.81 \\
\hline \multirow[t]{2}{*}{$31-40$ yrs } & Not Adjusted & $2 \times 10^{-5} * * *$ & $2 \times 10^{-6}\left(1.6 \times 10^{-5}-2.5 \times 10^{-5}\right)$ & 0.78 & & $2 \times 10^{-6}\left(-4 \times 10^{-6}-4 \times 10^{-6}\right)$ & 0.78 \\
\hline & VAT & $2.1 \times 10^{-5} * * *$ & $2 \times 10^{-6}\left(1.7 \times 10^{-5}-2.5 \times 10^{-5}\right)$ & 0.78 & 0 & $2 \times 10^{-6}\left(-4 \times 10^{-6}-4 \times 10^{-6}\right)$ & 0.78 \\
\hline \multirow[t]{2}{*}{$41-50$ yrs } & Not Adjusted & $1.3 \times 10^{-5} * * *$ & $1 \times 10^{-6}\left(1 \times 10^{-5}-1.6 \times 10^{-5}\right)$ & 0.79 & $3 \times 10^{-6 * *}$ & $1 \times 10^{-6}\left(1 \times 10^{-6}-5 \times 10^{-6}\right)$ & 0.79 \\
\hline & VAT & $1.3 \times 10^{-5} * * *$ & $1 \times 10^{-6}\left(1.1 \times 10^{-5}-1.6 \times 10^{-5}\right)$ & 0.79 & $3 \times 10^{-6 * *}$ & $1 \times 10^{-6}\left(1 \times 10^{-6}-5 \times 10^{-6}\right)$ & 0.79 \\
\hline \multirow[t]{2}{*}{$51-60$ yrs } & Not Adjusted & $1.2 \times 10^{-5} * * *$ & $1 \times 10^{-6}\left(9 \times 10^{-6}-1.4 \times 10^{-5}\right)$ & 0.78 & $1 \times 10^{-6}$ & $1 \times 10^{-6}\left(-1 \times 10^{-6}-3 \times 10^{-6}\right)$ & 0.78 \\
\hline & VAT & $1.3 \times 10^{-5} * * *$ & $1 \times 10^{-6}\left(1 \times 10^{-5}-1.5 \times 10^{-5}\right)$ & 0.79 & $1 \times 10^{-6}$ & $1 \times 10^{-6}\left(-1 \times 10^{-6}-3 \times 10^{-6}\right)$ & 0.79 \\
\hline \multirow[t]{2}{*}{$61-70$ yrs } & Not Adjusted & $6 \times 10^{-6 * * *}$ & $1 \times 10^{-6}\left(4 \times 10^{-6}-7 \times 10^{-6}\right)$ & 0.77 & $1 \times 10^{-6 *}$ & $1 \times 10^{-6}\left(-0.0-3 \times 10^{-6}\right)$ & 0.77 \\
\hline & VAT & $6 \times 10^{-6 * * *}$ & $1 \times 10^{-6}\left(5 \times 10^{-6}-8 \times 10^{-6}\right)$ & 0.78 & $1 \times 10^{-6 *}$ & $1 \times 10^{-6}\left(-0.0-3 \times 10^{-6}\right)$ & 0.78 \\
\hline \multirow[t]{2}{*}{$71-80$ yrs } & Not Adjusted & $1 \times 10^{-6 * * *}$ & $0.0\left(0.0-2 \times 10^{-6}\right)$ & 0.74 & $1 \times 10^{-6 *}$ & $0.0\left(-0.0-1 \times 10^{-6}\right)$ & 0.74 \\
\hline & VAT & $1 \times 10^{-6 * * *}$ & $0.0\left(0.0-2 \times 10^{-6}\right)$ & 0.74 & $1 \times 10^{-6 *}$ & $0.0\left(-0.0-1 \times 10^{-6}\right)$ & 0.74 \\
\hline \multirow{2}{*}{$81-90 \mathrm{yrs}$} & Not Adjusted & 0 & $0.0\left(-0.0-1 \times 10^{-6}\right)$ & 0.63 & the & $0.0\left(-0.0-1 \times 10^{-6}\right)$ & 0.63 \\
\hline & VAT & 0 & $0.0\left(-0.0-1 \times 10^{-6}\right)$ & 0.64 & 0 & $0.0\left(-0.0-1 \times 10^{-6}\right)$ & 0.64 \\
\hline
\end{tabular}

Notes: Each row represents two coefficients of two DID regression models, stay-at-home order and school closure regression models with normalized effects by population size in states, with state and date as fixed effects using Eq. 2. We controlled for COVID-19 confirmed cases to adjust the models using Eq. 4 for the TVA model

$* * * p<0.01$

$* * p<0.05$

$* p<0.1$ 